\title{
Green Synthesis, Antioxidant, and Plant Growth Regulatory Activities of Novel $\alpha$-Furfuryl-2-alkylaminophosphonates
}

\author{
Maheshwara Reddy Nadiveedhi, Poojith Nuthalapati, Mohan Gundluru, Mohan Reddy Yanamula, \\ Saritha Venkatareddy Kallimakula, Visweswara Rao Pasupuleti,* Vijaya Kumar Reddy Avula, \\ Swetha Vallela, Grigory Vasilievich Zyryanov, Satheesh Krishna Balam, and Suresh Reddy Cirandur*
}

Cite This: ACS Omega 2021, 6, 2934-2948

Read Online

\section{ACCESS | Lill Metrics \& More | 回 Article Recommendations | sl Supporting Information}

ABSTRACT: A series of novel $\alpha$-furfuryl-2-alkylaminophosphonates have been efficiently synthesized from the one-pot threecomponent classical Kabachnik-Fields reaction in a green chemical approach by addition of an in situ generated dialkylphosphite to Schiff's base of aldehydes and amines by using environmental and eco-friendly silica gel supported iodine as a catalyst by microwave irradiation. The advantage of this protocol is simplicity in experimental procedures and products were resulted in high isolated yields. The synthesized $\alpha$-furfuryl-2alkylaminophosphonates were screened to in vitro antioxidant and

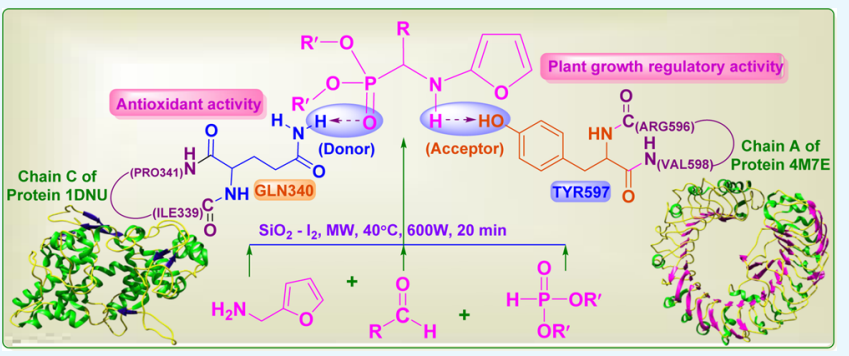
plant growth regulatory activities and some are found to be potent with antioxidant and plant growth regulatory activities. These in vitro studies have been further supported by ADMET (absorption, distribution, metabolism, excretion, and toxicity), quantitative structure-activity relationship, molecular docking, and bioactivity studies and identified that they were potentially bound to the GLN340 amino acid residue in chain C of 1DNU protein and TYR597 amino acid residue in chain A of 4M7E protein, causing potential exhibition of antioxidant and plant growth regulatory activities. Eventually, title compounds are identified as good bloodbrain barrier ( $\mathrm{BBB}$ )-penetrable compounds and are considered as proficient central nervous system active and neuroprotective antioxidant agents as the neuroprotective property is determined with BBB penetration thresholds.

\section{INTRODUCTION}

Organophosphorus chemistry research bestowed an elegant locus to $\alpha$-aminophosphonates as they have exhilarated with potential antioxidant, ${ }^{1}$ antifungal, ${ }^{2}$ antibacterial, ${ }^{3}$ antidiabetic, ${ }^{4}$ anticancer, ${ }^{5}$ antiviral, ${ }^{6}$ antitumor, ${ }^{7}$ cytotoxic, ${ }^{8}$ antiproliferative, ${ }^{9}$ antibiotic, ${ }^{10}$ antithrombotic, ${ }^{11}$ peptidomimetic, ${ }^{12}$ catalytic antibodies hapten, ${ }^{13}$ neuroactive enzyme inhibiting, and anti-bone resorption ${ }^{14}$ activities. As they are tetrahedral transition-state mimics, they are identified as HIV protease, ${ }^{15}$ synthase, ${ }^{16}$ serine hydrolase, ${ }^{17}$ and UDP-galactopyranose mutase ${ }^{18}$ inhibitors. They have also been identified as surrogates of both natural and synthetic $\alpha$-amino acids ${ }^{19}$ as constituted with significant motifs in medicine. In agriculture, phosphorus is identified as an essential element ${ }^{20,21}$ and is widely used in the production of crop fertilizers. They find their use as insecticides, $^{21}$ plant growth regulators, ${ }^{22-24}$ herbicides, ${ }^{25}$ pesticides, ${ }^{26}$ fungicides, ${ }^{27}$ and in photosynthesis as ADP and ATP. In the industry, they are used as additive polymers, ${ }^{28}$ surfactants, ${ }^{29}$ lubricants, ${ }^{29}$ surface treaters on metals, ${ }^{30}$ and flame retardants. ${ }^{31}$ In organic chemistry, ${ }^{32}$ they have been used as catalysts ${ }^{33}$ in coupling ${ }^{34}$ and complex reactions ${ }^{35}$ and also as catalytic promoters. ${ }^{36}$ Many aminophosphonic acids/peptides/ esters from both synthetic and natural origin have displayed an extensive array of biological activities. ${ }^{37}$ They act as substrates in the synthesis and development of impending drugs against various metabolic disorders. ${ }^{38}$

Owing to these, the synthesis of $\alpha$-aminophosphonates had grown more inquisitiveness in medicinal chemistry researchers to study their structure-activity relationship and to design some more potential libraries to the existing repositories. Although a number of synthetic methodologies have been reported to construct bioactive $\alpha$-aminophosphonates, ${ }^{39-42}$ the nucleophilic phosphite addition to Schiff's base is the utmost prevailing and modest method. Here, certain active catalysts such as titanium dioxide, boric acid, sulfonic acid functionalized ionic liquid, nanoporous AlSBA-15, ${ }^{43}$ Magnetic $\mathrm{BaFe}_{12} \mathrm{O}_{19} / \mathrm{Al}_{2} \mathrm{O}_{3}{ }^{44}$ and silica sulfuric acid ${ }^{45}$ are used with conventional heating, sonication, microwave irradiation in organic solvents, ${ }^{46}$ and even with simple grinding. Among them, reactions stimulated with ultrasonic/microwave irradiation led to the specific attention as these energizing

Received: October 30, 2020

Accepted: December 18, 2020

Published: January 21, 2021 
Scheme 1. Synthesis of $\alpha$-Furfuryl-2-alkylaminophosphonates $(5 a-j)$

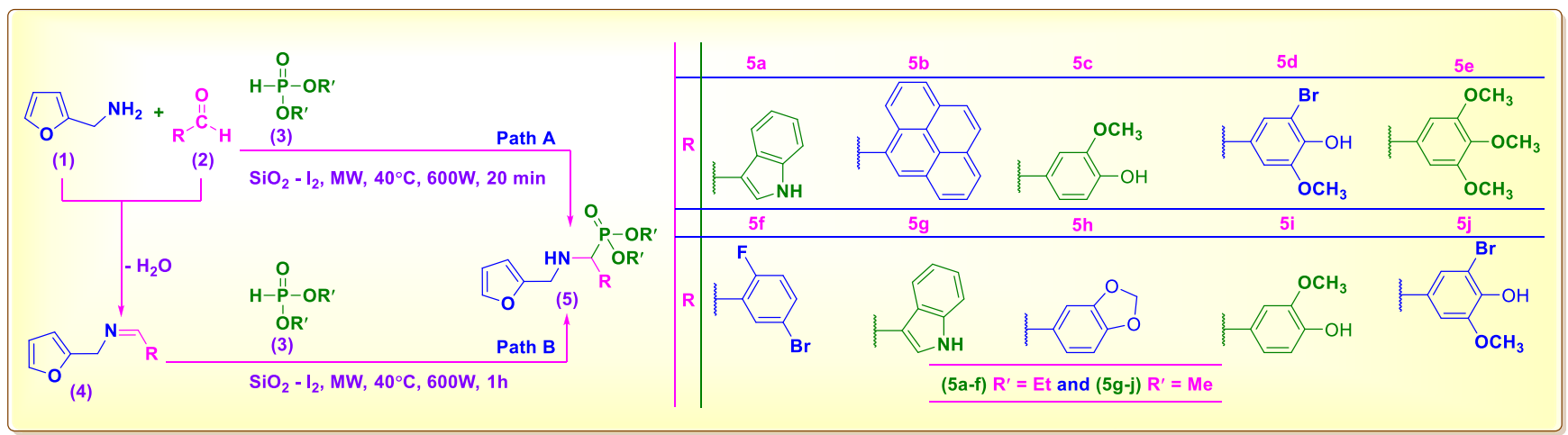

techniques advance the reaction and complete it in less time under trivial conditions and produces high yields and also more pronounced scientifically. Concerning the vitality of furfuryl and tetrahydrofurfuryl groups in pharmaceuticals, fibers, and perfumes, ${ }^{47-51}$ one-pot microwave KabachnikFields synthesis of some novel and structurally diversified $\alpha$ furfuryl-2-ethyl aminophosphonates $(\mathbf{5 a}-\mathbf{j})$ has been designed through the reaction of aryl aldehydes, furfurylamine, and dialkyl phosphonates (Scheme 1). The synthesized $\alpha$-furfuryl2-alkylaminophosphonates were structurally confirmed by physical characterization and spectral studies, and their antioxidant and plant growth regulatory activities have been evaluated by in silico and in vitro methods. Eventually, herein we describe the microwave-supported synthesis, spectral and physical characterization, and biological activity evaluation of novel furfurylamine-based $\alpha$-aminophosphonates. The additional studies such as molecular docking, quantitative structure-activity relationship (QSAR), and ADMET (absorption, distribution, metabolism, excretion, and toxicity) performed to study their bioactivity properties infer that the bioactive proficiency of $\mathbf{5 a}-\mathbf{j}$ has been administrated through a stereogenic $\alpha$-carbon's configuration bonded to phosphorus.

\section{RESULTS AND DISCUSSION}

2.1. Chemistry. Synthesis of diethyl (((furan-2-ylmethyl)amino) (4-hydroxy-3-methoxyphenyl)methyl) phosphonate) (5a) has been accomplished by two different reaction pathways $\mathrm{A}$ and $\mathrm{B}$. Path $\mathrm{A}$ involves a straight one-pot and threecomponent, $\mathrm{SiO}_{2}-\mathrm{I}_{2}$-catalyzed Kabachnik-Fields reaction of vanillin (2a), furfurylamine (1), and diethylphosphite (3a) promoted by microwave irradiation. In path $B$, the reaction is carried out through the addition of diethylphosphite (3a) to the vanillin-derived Schiff base, vanillinidene-furfurylamine (4) (Scheme 1); by following the same procedure, the remaining analogues of the series $(\mathbf{5 b}-\mathbf{j})$ have been synthesized.

2.1.1. Optimization of Reaction Conditions for the Synthesis of $5 a$. Both reactions were run under microwave irradiation at different conditions and observed that best product yields were obtained in both the pathways at $40{ }^{\circ} \mathrm{C}$ and $600 \mathrm{~W}$ (Table 1). Among the two reaction pathways, better product yields were obtained in path $\mathrm{A}$ in less time because of the synergic formation of Schiff's base from vanillin, furfurylamine, and addition of phosphite to it. However, in path $\mathrm{B}$, water formed during the formation of imine hydrolyzes the imine back to aldehyde that results in lower yields. We observed that the reaction goes slowly and takes $6 \mathrm{~h}$ to complete without any catalyst. When the reaction was
Table 1. Optimization of Synthesis of $5 \mathrm{a}^{a}$

\begin{tabular}{ccccc}
$\begin{array}{c}\text { temperature } \\
\left({ }^{\circ} \mathrm{C}\right)\end{array}$ & $\begin{array}{c}\text { microwave } \\
\text { irradiation }(\mathrm{W})\end{array}$ & $\begin{array}{c}\text { catalyst } \\
(10 \mathrm{~mol} \%)\end{array}$ & $\begin{array}{c}\text { time } \\
(\mathrm{min})\end{array}$ & $\begin{array}{c}\text { isolated yield } \\
(\%)^{b}\end{array}$ \\
25 & 100 & - & 60 & 10.24 \\
25 & 200 & - & 60 & 12.49 \\
25 & 300 & - & 60 & 15.17 \\
25 & 400 & - & 60 & 20.66 \\
25 & 500 & - & 60 & 25.48 \\
25 & 600 & - & 60 & 32.59 \\
25 & 700 & - & 60 & 32.38 \\
25 & 800 & - & 60 & 20.27 \\
30 & 600 & - & 60 & 32.69 \\
40 & 600 & - & 60 & 35.74 \\
50 & 600 & - & 60 & 35.93 \\
60 & 600 & - & 60 & 25.87 \\
40 & 600 & $\mathrm{Al}_{2} \mathrm{O}_{3}$ & 45 & 51.79 \\
40 & 600 & $\mathrm{SiO}_{2}$ & 42 & 66.30 \\
40 & 600 & $\mathrm{Al}\left(\mathrm{OTf}_{3}\right.$ & 40 & 70.52 \\
40 & 600 & $\mathrm{nano}_{2} \mathrm{O}_{3}$ & 43 & 57.95 \\
40 & 600 & $\mathrm{BF}_{3} \mathrm{EtO}_{2}$ & 40 & 63.41 \\
40 & 600 & $\mathrm{I}_{2}$ & 35 & 76.54 \\
40 & 600 & $\mathrm{SiO}_{2}-\mathrm{I}_{2}$ & 20 & 92.29 \\
\hline
\end{tabular}

${ }^{a}$ Reaction conditions: diethyl phosphite (3a), vanillin-derived Schiff base (4), and $\mathrm{SiO}_{2}-\mathrm{I}_{2}$ as the catalyst. ${ }^{b}$ Isolated yield.

conducted with different catalysts such as $\mathrm{Al}_{2} \mathrm{O}_{3}, \mathrm{SiO}_{2}$, $\mathrm{Al}(\mathrm{OTf})_{3}$, and $\mathrm{BF}_{3} \cdot \mathrm{Et}_{2} \mathrm{O}$, moderate product yields (35-45\%) were obtained. When the reaction was conducted in $10 \mathrm{~mol} \%$ of $\mathrm{SiO}_{2}-\mathrm{I}_{2}$, a great increase in the rate of reaction yields in lesser times takes place. At the outset, it was thought that $\mathrm{SiO}_{2}-\mathrm{I}_{2}$ was acquainted for catalytic support; besides, kinetic studies have revealed that it enhances the rate of reaction because of its acidic characteristic and ease of binding of silicone with several atoms of the substrates. Recently, several research groups have utilized some silica-supported catalysts such as $\mathrm{SiO}_{2}-\mathrm{CeCl}_{2}$ and $\mathrm{SiO}_{2}-\mathrm{ZnCl}_{2}{ }^{52}$ effectively to synthesize $\alpha$-amino/carbamoyl/carbamothioyl phosphonates.

In addition, iodine was used as a catalyst owing to its abundant availability and low cost, ease of handling, stability, and use in numerous chemical transformations. ${ }^{53,54}$ Further, the catalyst mixture $\mathrm{SiO}_{2}-\mathrm{I}_{2}$ was prepared from iodine and silica gel (100-200 mesh) in a 2:1 ratio. It worked as a heterogeneous catalyst and conveniently handled and separated from the reaction mixture through filtration for reuse and is environment-friendly. To our best knowledge, the $\mathrm{SiO}_{2}-\mathrm{I}_{2}$ catalyst has not been reported to synthesize $\alpha$-aminophosphonates, and hence, we have explored the one-pot and 
three-component Kabachnik-Fields synthesis of $\alpha$-furfuryl-2alkylamino-phosphonates under heterogeneous catalytic action of $\mathrm{SiO}_{2}-\mathrm{I}_{2}$ in association with solvent-free, microwave irradiation conditions.

Hence, the finest conditions for reacting $2.0 \mathrm{mmol}$ of aldehyde (2) and furfurylamine (1) with $2.1 \mathrm{mmol}$ of dialkylphosphite (3) and $10 \mathrm{~mol} \%$ of $\mathrm{SiO}_{2}-\mathrm{I}_{2}$ under microwave irradiation and neat conditions have accomplished

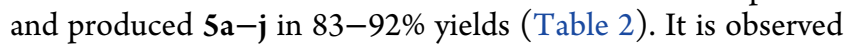

Table 2. Reaction Time and Yield of the Products $5 a-j$

\begin{tabular}{ccc} 
entry & reaction time $(\mathrm{min})$ & isolated yield $(\%)$ \\
\cline { 1 - 1 } $\mathbf{5 a}$ & 20 & 92.35 \\
$\mathbf{5 b}$ & 22 & 90.42 \\
$\mathbf{5 c}$ & 15 & 95.28 \\
$\mathbf{5 d}$ & 22 & 89.41 \\
$\mathbf{5 e}$ & 15 & 96.53 \\
$\mathbf{5 f}$ & 25 & 85.17 \\
$\mathbf{5 g}$ & 20 & 90.34 \\
$\mathbf{5 h}$ & 25 & 83.76 \\
$\mathbf{5 i}$ & 15 & 93.89 \\
$\mathbf{5 j}$ & 22 & 85.06
\end{tabular}

that this reaction method is applicable to a wide range of aromatic aldehydes (electron-rich as well as electron-deficient) and diethyl and dimethyl phosphites and that the reactions proceed smoothly in 20-30 $\mathrm{min}$ and produced $\mathbf{5 a}-\mathbf{j}$ in excellent isolated yields. Eventually, it is noticed that the effect of electron-withdrawing groups on the carbonyl compound decreases the product yield and also increases the reaction time, while the effect of electron-releasing groups on carbonyl compound increases the product yield and decreases the reaction time.

2.1.2. Plausible Reaction Mechanism for the Synthesis of $\mathbf{5 a}-\mathbf{j}$. Obviously, this reaction is a multistep procedure with the transition state having a quite complex mechanism (Figure 1). In fact, in the first step, the catalyst has greatly promoted the reaction by the virtue of acidic nature of silicon, is well influenced by iodine by withdrawing electrons from silica, and activates electrophilically the carbonyl carbon of the aldehyde

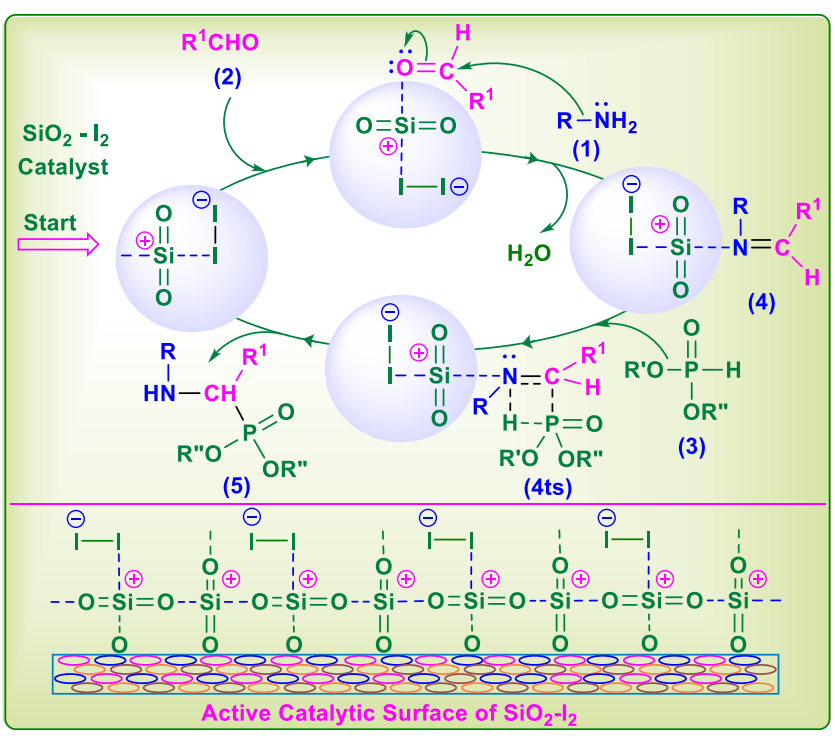

Figure 1. Mechanism for $\mathrm{SiO}_{2}-\mathrm{I}_{2}$-catalyzed synthesis.
(2), which facilitates nucleophilic substitution by the amine (1) to form the imine (4).

Because its formation is a reversible process, it is trapped immediately by the catalyst as a four-membered iminephosphite $-\mathrm{SiO}_{2}-\mathrm{I}_{2}$ complex transition state (4ts). Formation of 4 ts not only prevents hydrolysis of the imine substrate (4) to the amine (1) and aldehyde (2) by water formed during the condensation of amine (1) and aldehyde that also force the reaction forward. The $\mathrm{SiO}_{2}-\mathrm{I}_{2}$ catalyst coordinates to the nitrogen atom of $4 \mathrm{ts}$ renders it more electron rich by attracting the electron density of imino bond and facilitates concerted break-up of 4ts in such a way as to lead to the nucleophilic addition of phosphino phosphorus to the iminocarbon atom and electrophilic addition of hydrogen to the iminonitrogen atom to form $\alpha$-aminophosphonate (5) with simultaneous release of the catalyst.

2.2. Antioxidant Activity. The title compounds were screened for in vitro plant growth and antioxidant activities and supported by molecular docking studies. Compounds which inhibit the oxidation are known to be antioxidants. If oxidation takes place, then there is a chance of formation of free radicals, which leads to chain reactions that may damage the active cells. Hence, the main aim of the antioxidants is to inhibit generation of free radicals, thereby protecting the active cells. ${ }^{5-58}$ To evaluate the capacity of antioxidants, different types of methods are developed, and among them, 1,1-diphenyl-2picrylhydrazyl (DPPH) and $\mathrm{H}_{2} \mathrm{O}_{2}$ methods are more popular and effective. Hence, the synthesized novel $\alpha$-furfuryl-2ethylaminophosphonates $(\mathbf{5 a} \mathbf{- j})$ are screened for antioxidant activity by these methods.

2.2.1. DPPH Radical Scavenging Assay. Compounds 5a-j were subjected to free radical scavenging in vitro by the DPPH radical assay; ${ }^{59}$ the $\mathrm{IC}_{50}$ value denotes the concentration of the compound that inhibits $50 \%$ process of oxidation and is obtained by plotting the concentration versus percentage of inhibition graph and the obtained $\mathrm{IC}_{50}$ values shown against their compounds (Figure 2). Among the synthesized

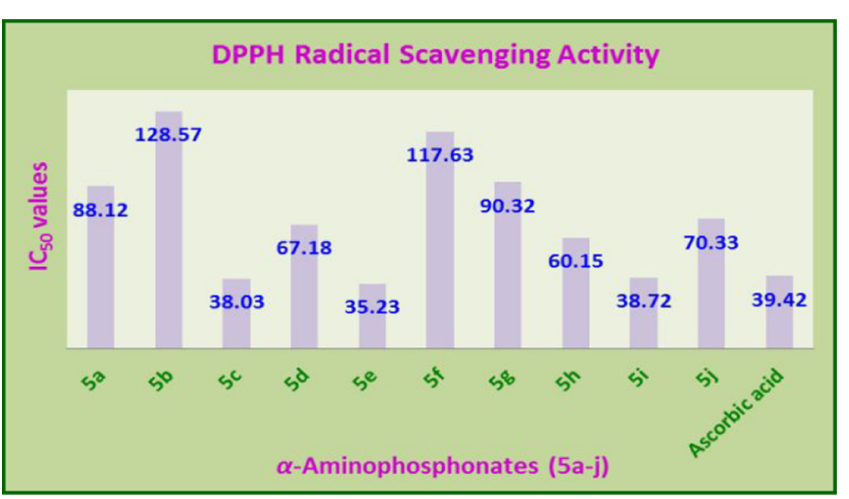

Figure 2. DPPH radical scavenging activity of $\mathbf{5 a}-\mathbf{j}$.

compounds $\mathbf{5 a}-\mathbf{j}, \mathbf{5 e}\left(\mathrm{IC}_{50}=35.23\right)$ showed higher bioactivity compared to standard ascorbic acid $\left(\mathrm{IC}_{50}=39.42\right)$. Also, $5 \mathrm{c}$ (38.03) and $\mathbf{5 i}$ (38.72) showed good results in comparison to ascorbic acid. Perhaps their significant activities are due to the presence of electron-donating methoxy $\left(-\mathrm{OCH}_{3}\right)$ and hydroxy $(-\mathrm{OH})$ substitutions in $\mathbf{5 c}, \mathbf{5 i}$ at meta and para position, respectively. In $\mathbf{5 e}$, the two methoxy groups at the meta position being less conjugated than the methoxy group located at the para position delivers additional electron density to 
overcome oxidation. The identical process in hydroxyl group present in $\mathbf{5 c}$ and $\mathbf{5 i}$, but which are less compared to methoxy group, hydroxyl group and hence they have shown less antioxidant activity than 5e. Furthermore, the presence of electron-withdrawing groups in $\mathbf{5 f}$ (fluorine at the ortho position and bromine at the meta position) decreases the availability of electrons and is responsible for the lower activity.

2.2.2. $\mathrm{H}_{2} \mathrm{O}_{2}$ Radical Scavenging Assay. In practice, the hydroxyl free radical scavenging assay of $\mathbf{5 a - j}$ has been performed by deoxyribose method ${ }^{60}$ and was referenced to ascorbic acid standard. In $\mathrm{H}_{2} \mathrm{O}_{2}$ radical scavenging assay, the compound 5e $\left(\mathrm{IC}_{50}=35.38\right)$ exhibited noteworthy activity than the standard ascorbic acid (39.57), whereas compounds 5c (37.03) and 5i (38.72) exhibit moderate activities (Figure 3 ). Here also, the same structure-activity has been observed

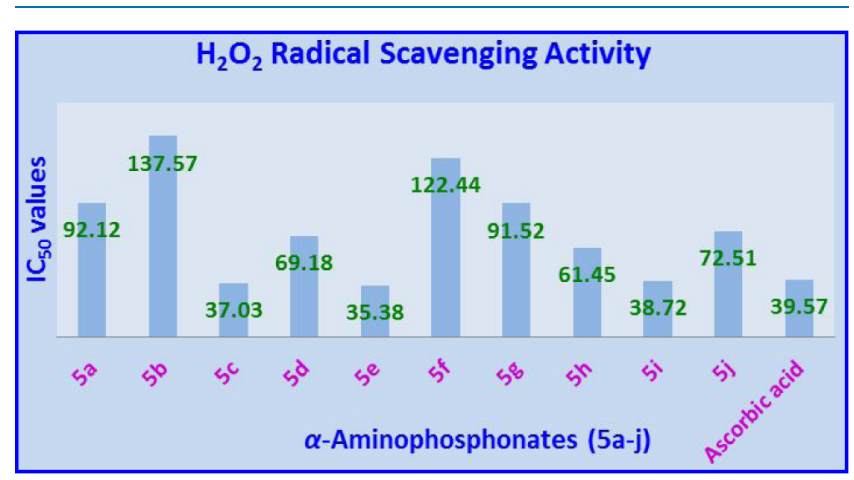

Figure 3. $\mathrm{H}_{2} \mathrm{O}_{2}$ radical scavenging activity of $\mathbf{5 a}-\mathbf{j}$.

among the series of compounds as noticed in the DPPH radical scavenging assay. The results obtained from $\mathrm{DPPH}$ and $\mathrm{H}_{2} \mathrm{O}_{2}$ free radical scavenging assays followed the linear correlation and is comparable to each other. It is not necessary that the $\mathrm{OH}$ group alone shows antioxidant activity. The concept of electron donor and acceptor also plays a very important role in the redox reactions. Therefore, any functional group which is capable of donating electrons may act as a good antioxidant. Among the synthesized title compounds, 5c, 5e, and $\mathbf{5 i}$ showed relatively higher antioxidant activity potentiality compared to standard ascorbic acid.

2.3. Plant Growth Activity. As organophosphorus compounds are bioactive toward both animals and plants and in such aminophosphonates are comparatively more potent than glyphosate in terms of biological activity. It is analyzed and identified that the biological activity of title compounds intensely correlates with the lipophilic characteristic of Trakephon and hence also resembles the plant growth regulatory activity. ${ }^{61}$ Therefore, it is precisely credible that the action of title compounds is linked with distracting plant membrane's function as proposed by many researchers. Based on this notion, we have analyzed the effect of prepared $\alpha$ furfuryl-2-ethylaminophosphonates $(\mathbf{5 a}-\mathbf{j})$ differentiated by the nature of groups substituted on the phosphoryl phosphorus and carbonyl carbon atoms and hence indicating diverse polarity and hydrophobicity properties. Their plant growth regulatory activity was tested on roots and shoots of aquatic plant sorghum bicolor, using the technique of Smith and Fowden. ${ }^{62}$

The results demonstrated that all the compounds $(\mathbf{5 a}-\mathbf{j})$ clearly influenced the growth of the plant roots as well as shoots, but their effect on shoots is slightly less than that on the roots. Compound 5c at 100 ppm showed highest root length $(7.06 \mathrm{~cm})$, and compound 5 e showed highest shoot length $(1.96 \mathrm{~cm})$. Further the point of structure-activity relationships, compounds substituted with electron-releasing groups in the aromatic ring $(\mathbf{5 c}, \mathbf{5} \mathbf{f}$, and $\mathbf{5 j}$ ) promoted growth, while those substituted with electron-withdrawing groups (5f) inhibit the growth of the root. However, in the case of $\mathbf{5 d}$ and $\mathbf{5 j}$, the presence of both electron-withdrawing and hydroxyl groups showed moderate results. In the case of effect on shoot lengths, all the compounds showed mostly equal effect. With respect to the effect of concentration of the compound in solution, plant growth also increases with the increase of concentration of the compound. The results are represented in Figure 4.

2.4. Molecular Docking Studies. The in vitro DPPH and $\mathrm{H}_{2} \mathrm{O}_{2}$ radical scavenging activity and plant growth regulatory activity of $\mathbf{5 a}-\mathbf{j}$ have been supported by their binding potentialities against the considered enzymatic protein chains as revealed based on molecular docking studies. Here, the molecular docking was executed for the structures of $\mathbf{5 a - j}$ against the target protein receptors in chain $\mathrm{C}$ of $1 \mathrm{DNU}$ (human myeloperoxidase-thiocyanate complex) protein and chain A of 4M7E (BL-induced activation of the BRI1-BAK1 complex) protein, respectively, for the antioxidant and plant growth regulatory activities to study their protein-ligand binding interactions.

The potential binding modes of amino acid residues against hydrogen bond acceptor and donor atoms of $\mathbf{5 a - j}$ and their docking poses are presented in Tables 3-6. The binding specificity of $\mathbf{5 a}-\mathbf{j}$ with chain C (containing 466 amino acids)

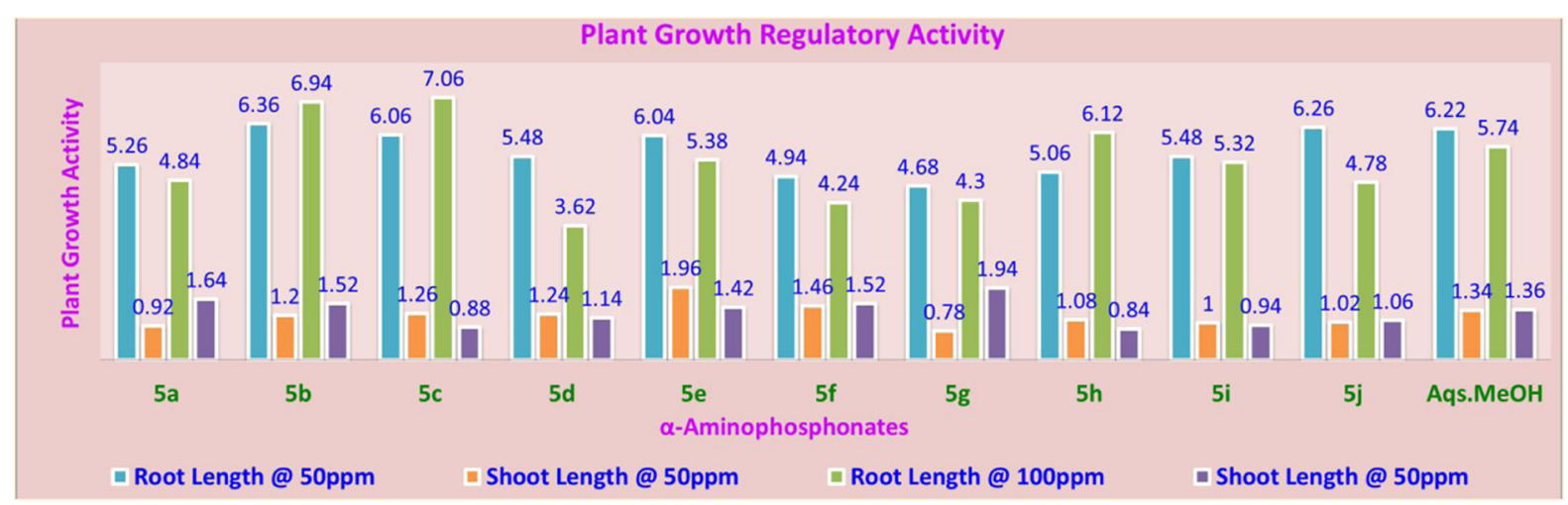

Figure 4. Plant growth regulatory activity of compounds $\mathbf{5 a}-\mathbf{j}$. 
Table 3. Potential Protein-Ligand Interactions of $5 a-j$ with Chain C of Protein 1DNU at GLN340 Amino Acid Residue ${ }^{a}$
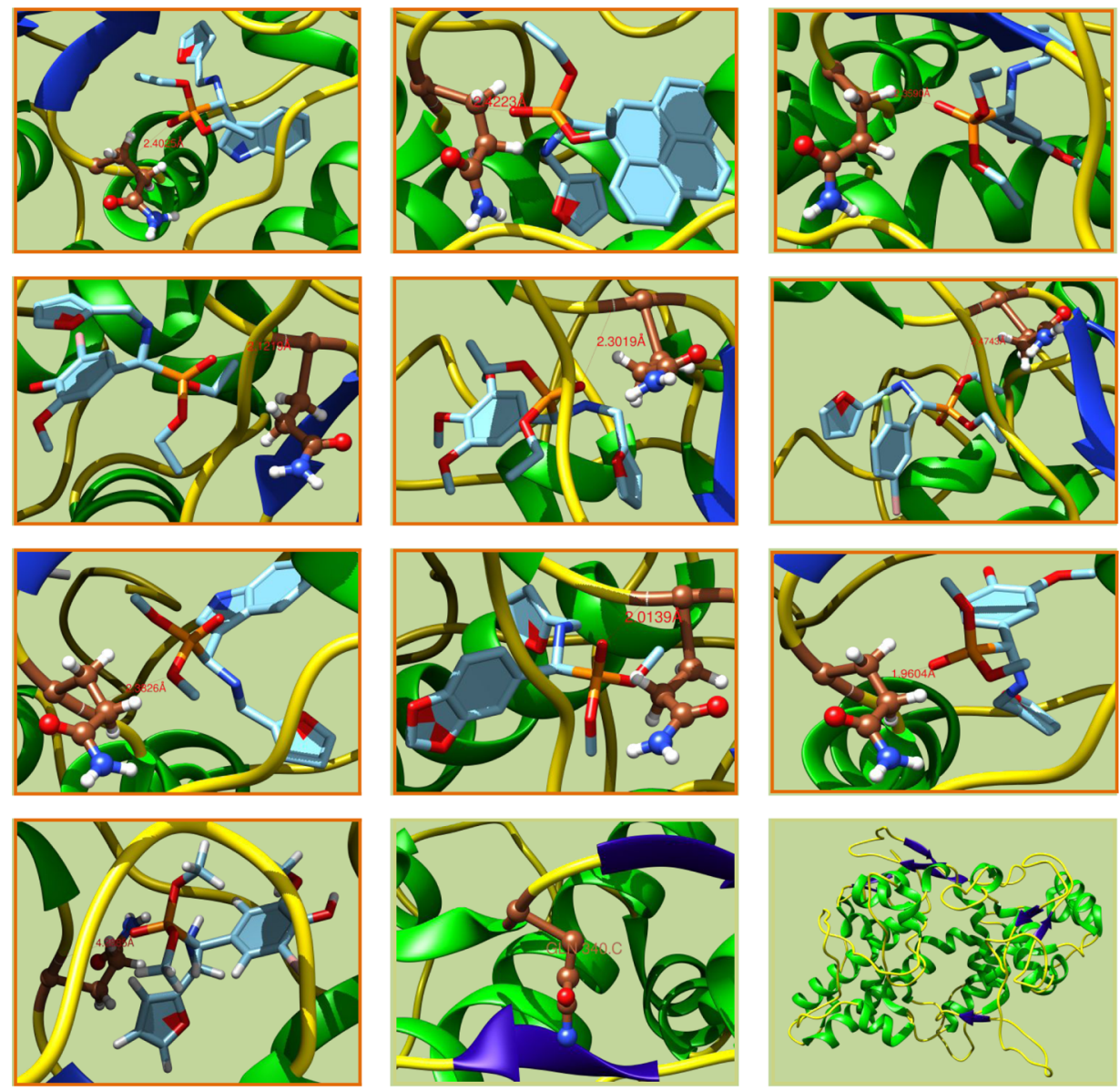

${ }^{a}$ Docking poses of $\mathbf{5 a}-\mathbf{j}$, GLN340 in chain C of 1DNU protein and chain C of 1DNU protein (in order-top left to bottom right).

Table 4. Molecular Docking Interactions of 5a-j with Chain $\mathrm{C}$ of Protein 1DNU at GLN340 Amino Acid Residue

\begin{tabular}{|c|c|c|c|c|c|c|c|c|c|}
\hline $\begin{array}{l}\text { S. } \\
\text { no. }\end{array}$ & $\begin{array}{l}\text { cluster } \\
\text { number }\end{array}$ & $\begin{array}{l}\text { cluster } \\
\text { rank }\end{array}$ & $\begin{array}{l}\text { binding energy } \\
(\mathrm{kcal} / \mathrm{mol})\end{array}$ & $\begin{array}{l}\text { no. of hydrogen } \\
\text { bonds }\end{array}$ & $\begin{array}{l}\text { H-bond ligand } \\
\text { atoms }\end{array}$ & $\begin{array}{l}\text { H-bond receptor } \\
\text { atoms }\end{array}$ & binding interaction & $\begin{array}{l}\text { bond length } \\
(\AA)\end{array}$ & $\begin{array}{l}\text { H-bond } \\
\text { type }\end{array}$ \\
\hline $5 a$ & 4 & 1 & -8.2531 & 1 & 1 & 1 & $\underset{\text { GLN340 }}{\operatorname{ligand}(\mathrm{P}=\mathrm{O}) \cdots(\mathrm{HN})}$ & 2.4025 & donor \\
\hline $5 b$ & 1 & 4 & -9.2938 & 1 & 1 & 1 & $\underset{\text { GLN340 }}{\operatorname{ligand}(\mathrm{P}=\mathrm{O}) \cdots(\mathrm{HN})}$ & 2.4223 & donor \\
\hline $5 \mathrm{c}$ & 0 & 0 & -8.2422 & 1 & 1 & 1 & $\underset{\text { GLN340 }}{\operatorname{ligand}(\mathrm{P}=\mathrm{O}) \cdots(\mathrm{HN})}$ & 2.3590 & donor \\
\hline $5 d$ & 5 & 5 & -8.6906 & 1 & 1 & 1 & $\underset{\text { GLN340 }}{\operatorname{ligand}(\mathrm{P}=\mathrm{O}) \cdots(\mathrm{HN})}$ & 2.1219 & donor \\
\hline $5 e$ & 4 & 3 & -9.2858 & 1 & 1 & 1 & $\underset{\text { GLN340 }}{\operatorname{ligand}(\mathrm{P}=\mathrm{O}) \cdots(\mathrm{HN})}$ & 2.3019 & donor \\
\hline $5 f$ & 19 & 0 & -8.0713 & 1 & 1 & 1 & $\underset{\mathrm{GLN} 340}{\operatorname{ligand}[\mathrm{P}=\mathrm{O}] \cdots(\mathrm{HN})}$ & 2.4743 & donor \\
\hline $5 g$ & 0 & 0 & -7.7212 & 1 & 1 & 1 & $\underset{\text { GLN340 }}{\operatorname{ligand}[\mathrm{P}=\mathrm{O}] \cdots(\mathrm{HN})}$ & 2.3626 & donor \\
\hline $5 \mathrm{~h}$ & 0 & 1 & -8.2572 & 1 & 1 & 1 & $\underset{\text { GLN340 }}{\operatorname{ligand}(\mathrm{P}=\mathrm{O}) \cdots(\mathrm{HN})}$ & 2.0139 & donor \\
\hline $5 \mathrm{i}$ & 0 & 11 & -8.3254 & 1 & 1 & 1 & $\underset{\text { GLN340 }}{\operatorname{ligand}(\mathrm{P}=\mathrm{O}) \cdots(\mathrm{HN})}$ & 1.9604 & donor \\
\hline $5 \mathbf{j}$ & 0 & 1 & -8.4110 & 1 & 1 & 1 & $\underset{\mathrm{GLN} 340}{\operatorname{ligand}(\mathrm{P}=\mathrm{O}) \cdots(\mathrm{HN})}$ & 2.3885 & donor \\
\hline
\end{tabular}

of 1DNU (myeloperoxidase) protein has confirmed their antioxidant potentiality as they were intensely bound with the glutamine amino acid residue (GLN340) located at the 340 position of the amino acid series in the chain. This assures the core interaction of synthesized compounds at the central position of chain $\mathrm{C}$, which is a valid consideration to support antioxidant activity in vitro.

Remarkably, they were bound to GLN340 with a binding energy of -9.2938 to $-7.7212 \mathrm{kcal} / \mathrm{mol}$ with a rational bond length of 1.9604-2.4743 $\AA$ in forming hydrogen bonds. Profoundly, compounds $5 \mathbf{a}-\mathbf{j}$ formed hydrogen bonding with 
Table 5. Potential Protein-Ligand Interactions of 5a-j with Chain A of Protein 4M7E at TYR597 Amino Acid Residue ${ }^{a}$
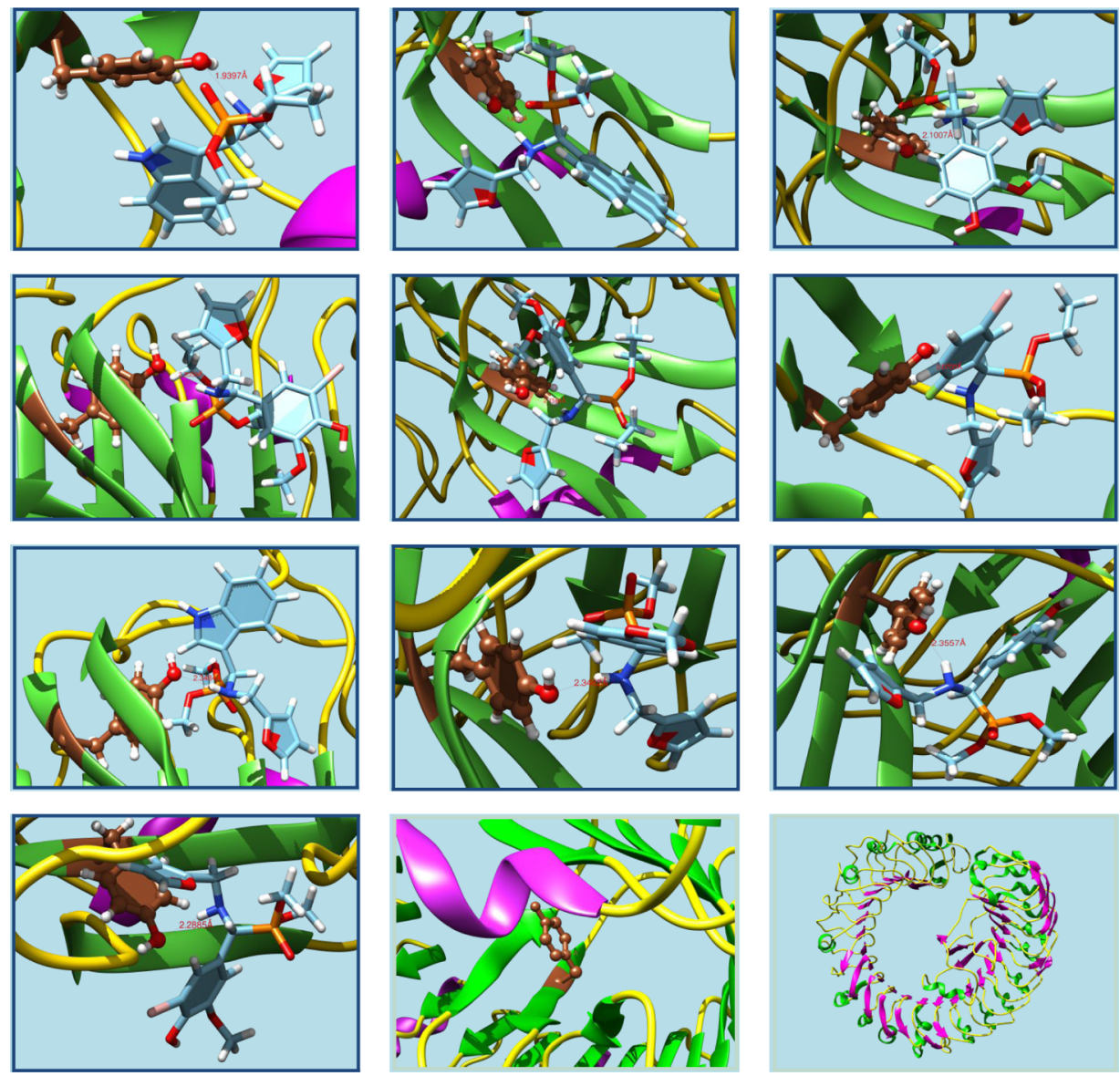

${ }^{a}$ Docking poses of $\mathbf{5 a}-\mathbf{j}$, TYR597 in chain A of 4M7E protein and chain A of 4M7E protein (in order-top left to bottom right).

Table 6. Molecular Docking Interactions of 5a-j with Chain A of Protein 4M7E at TYR597 Amino Acid Residue

\begin{tabular}{|c|c|c|c|c|c|c|c|c|c|}
\hline $\begin{array}{l}\text { S. } \\
\text { no. }\end{array}$ & $\begin{array}{l}\text { cluster } \\
\text { number }\end{array}$ & $\begin{array}{l}\text { cluster } \\
\text { rank }\end{array}$ & $\begin{array}{l}\text { binding energy } \\
(\mathrm{kcal} / \mathrm{mol})\end{array}$ & $\begin{array}{l}\text { no. of hydrogen } \\
\text { bonds }\end{array}$ & $\begin{array}{l}\text { H-bond ligand } \\
\text { atoms }\end{array}$ & $\begin{array}{l}\text { H-bond } \\
\text { receptor atoms }\end{array}$ & binding interaction & $\begin{array}{c}\text { bond } \\
\text { length }(\AA)\end{array}$ & $\begin{array}{l}\text { H-bond } \\
\text { type }\end{array}$ \\
\hline $5 a$ & 2 & 1 & -8.0654 & 1 & 1 & 1 & $\begin{array}{l}\text { ligand }(\mathrm{P}-\mathrm{C}(\mathrm{H})-\mathrm{NH}) \ldots \\
\quad(\mathrm{O}-\mathrm{H}) \mathrm{TYR} 597\end{array}$ & 1.9397 & acceptor \\
\hline $5 b$ & 33 & 1 & -8.1484 & 1 & 1 & 1 & $\begin{array}{l}\text { ligand }(\mathrm{P}-\mathrm{C}(\mathrm{H})-\mathrm{NH}) \ldots \\
\quad(\mathrm{O}-\mathrm{H}) \mathrm{TYR} 597\end{array}$ & 1.9236 & acceptor \\
\hline $5 c$ & 0 & 0 & -7.9312 & 1 & 1 & 1 & $\begin{array}{l}\text { ligand }(\mathrm{P}-\mathrm{C}(\mathrm{H})-\mathrm{NH}) \ldots \\
(\mathrm{O}-\mathrm{H}) \mathrm{TYR} 597\end{array}$ & 2.1007 & acceptor \\
\hline $5 d$ & 6 & 6 & -7.9150 & 1 & 1 & 1 & $\begin{array}{l}\text { ligand }(\mathrm{P}-\mathrm{C}(\mathrm{H})-\mathrm{NH}) \cdots \\
\quad(\mathrm{O}-\mathrm{H}) \mathrm{TYR} 597\end{array}$ & 2.3359 & acceptor \\
\hline 5e & 20 & 1 & -7.8425 & 1 & 1 & 1 & $\begin{array}{l}\underset{(\mathrm{O} \text { ligand }(\mathrm{P}-\mathrm{C}(\mathrm{H}) \mathrm{H})-\mathrm{NH} 597}{ }\end{array}$ & 2.7589 & acceptor \\
\hline $5 f$ & 40 & 0 & -7.6491 & 1 & 1 & 1 & $\begin{array}{l}\text { ligand }(\mathrm{P}-\mathrm{C}(\mathrm{H})-\mathrm{NH}) \ldots \\
\quad(\mathrm{O}-\mathrm{H}) \mathrm{TYR} 597\end{array}$ & 2.0703 & acceptor \\
\hline $5 g$ & 1 & 3 & -7.6353 & 1 & 1 & 1 & $\begin{array}{l}\underset{(\mathrm{O}-\mathrm{H}) \mathrm{TYR} 597}{\operatorname{ligand}(\mathrm{P}-\mathrm{C}(\mathrm{H})-\mathrm{NH}) \cdots} \\
\end{array}$ & 2.3484 & acceptor \\
\hline $5 \mathrm{~h}$ & 2 & 1 & -7.8134 & 1 & 1 & 1 & $\begin{array}{l}\text { ligand }(\mathrm{P}-\mathrm{C}(\mathrm{H})-\mathrm{NH}) \cdots \\
\quad(\mathrm{O}-\mathrm{H}) \mathrm{TYR} 597\end{array}$ & 2.3462 & acceptor \\
\hline $5 \mathrm{i}$ & 21 & 2 & -7.9364 & 1 & 1 & 1 & $\begin{array}{l}\text { ligand }(\mathrm{P}-\mathrm{C}(\mathrm{H})-\mathrm{NH}) \ldots \\
\quad(\mathrm{O}-\mathrm{H}) \mathrm{TYR} 597\end{array}$ & 2.3557 & acceptor \\
\hline $5 j$ & 22 & 1 & -7.3909 & 1 & 1 & 1 & $\begin{array}{l}\text { ligand }(\mathrm{P}-\mathrm{C}(\mathrm{H})-\mathrm{NH}) \ldots \\
(\mathrm{O}-\mathrm{H}) \text { TYR597 }\end{array}$ & 2.2885 & acceptor \\
\hline
\end{tabular}

GLN340 as an oxygen atom of the phosphoryl group has been strongly bound to an amino hydrogen atom of the amide bond present on the glutamine; hence, here the title compounds act as the electron cloud donors in forming the hydrogen bond. Similarly, the binding specificity of $\mathbf{5 a - j}$ with chain A (containing 767 amino acids) of 4M7E (brassinosteroid insensitive 1) protein has confirmed their plant growth regulatory activity as they were intensely bound with tyrosine amino acid residue (TYR597) located at the 597 position of the amino acid series in the chain. This assures the core interaction of synthesized compounds at central position of chain A, which is a valid consideration to support plant growth 
Table 7. ADMET Properties of $5 \mathrm{a}-\mathrm{j}$

\begin{tabular}{|c|c|c|c|c|c|c|}
\hline entry & $\begin{array}{l}\text { in vivo } \mathrm{BBB} \text { penetration } \\
(\mathrm{C} . \text { brain/C.blood })^{a}\end{array}$ & $\begin{array}{l}\text { in vitro Caco- } 2 \text { cell } \\
\text { permeability }(\mathrm{nm} / \mathrm{s})^{b}\end{array}$ & $\begin{array}{c}\text { human intestinal } \\
\text { absorption(HIA, \%) }^{c}\end{array}$ & $\begin{array}{l}\text { in vitro MDCK cell } \\
\text { permeability }(\mathrm{nm} / \mathrm{s})^{d}\end{array}$ & $\begin{array}{l}\text { in vitro plasma protein } \\
\text { binding }(\%)^{e}\end{array}$ & toxicity $^{f}$ \\
\hline $5 a$ & 1.2749 & 21.7129 & 89.5313 & 191.0100 & 95.7056 & negative \\
\hline $5 b$ & 2.5729 & 21.7217 & 97.2754 & 79.4515 & 99.2126 & negative \\
\hline $5 c$ & 0.4368 & 21.7072 & 89.8057 & 122.3450 & 90.6733 & negative \\
\hline $5 d$ & 0.4900 & 18.8444 & 94.9217 & 27.9760 & 91.1146 & negative \\
\hline $5 e$ & 0.6212 & 21.7231 & 94.1342 & 74.8857 & 96.2773 & negative \\
\hline $5 f$ & 1.2911 & 21.4068 & 96.4950 & 38.0802 & 98.2989 & negative \\
\hline $5 \mathrm{~g}$ & 0.7318 & 21.6890 & 88.5328 & 186.4370 & 93.6175 & negative \\
\hline $5 h$ & 0.4699 & 21.7074 & 92.7086 & 87.8067 & 93.2263 & negative \\
\hline $5 i$ & 0.4518 & 21.6737 & 86.9710 & 122.9902 & 94.1828 & negative \\
\hline $5 j$ & 0.4560 & 16.1225 & 94.4193 & 29.6239 & 94.1007 & negative \\
\hline
\end{tabular}

${ }^{a}$ BBB penetration $=[$ brain $] /[$ blood $] .{ }^{b}$ Caco-2 cells derived from human colon adenocarcinoma, possessing multiple drug transport pathways through intestinal epithelium. ${ }^{c}$ HIA (human intestinal absorption), the sum of absorption and bioavailability evaluated from ratio of excretion in urine, bile, and feces. ${ }^{d}$ MDCK cell system is used as a tool for rapid permeability screening. ${ }^{e} \%$ of drug that binds to plasma protein. ${ }^{f}$ In vitro Ames test by metabolic and nonmetabolic activated TA100 and TA1535 strains collected from rat liver homogenate.

Table 8. Molecular Descriptor Properties of $5 a-j^{a}$

\begin{tabular}{|c|c|c|c|c|c|c|c|c|c|c|c|c|c|c|c|}
\hline \multirow[b]{2}{*}{ entry } & \multicolumn{6}{|c|}{ Lipinski parameters } & \multicolumn{3}{|c|}{ Veber parameters } & \multicolumn{6}{|c|}{ other parameters } \\
\hline & MW & $\begin{array}{l}\text { HB } \\
\text { Don }\end{array}$ & $\begin{array}{l}\mathrm{HB} \\
\mathrm{Acc}\end{array}$ & $\begin{array}{l}\log P \\
(\mathrm{o} / \mathrm{w})\end{array}$ & MR & $\begin{array}{l}\text { Lip. } \\
\text { Vio. }\end{array}$ & TPSA & $\begin{array}{c}\text { no. of } \\
\text { RB }\end{array}$ & $\begin{array}{l}\text { Veb. } \\
\text { Vio. }\end{array}$ & $\begin{array}{l}\text { no. } \\
\text { of } \mathrm{H}\end{array}$ & V. Vol. & $\rho$ & $S$ & CLP & $\% \mathrm{ABS}$ \\
\hline $5 a$ & 362.37 & 6 & 2 & 2.08 & 96.64 & 0 & 86.30 & 9 & 0 & 25 & 325.07 & 1.246 & -3.61 & 2.52 & 79.23 \\
\hline $5 b$ & 447.47 & 5 & 1 & 4.24 & 126.18 & 0 & 60.71 & 9 & 0 & 32 & 400.65 & 1.275 & -3.54 & 3.19 & 88.06 \\
\hline $5 c$ & 369.35 & 7 & 2 & 2.23 & 93.67 & 0 & 99.97 & 10 & 0 & 25 & 329.66 & 1.228 & -2.81 & 1.74 & 74.51 \\
\hline $5 d$ & 448.25 & 7 & 2 & 3.02 & 101.3 & 0 & 99.97 & 10 & 0 & 26 & 347.54 & 1.414 & -3.64 & 2.46 & 74.51 \\
\hline $5 e$ & 413.41 & 8 & 1 & 2.01 & 104.91 & 0 & 98.20 & 12 & 0 & 28 & 372.73 & 1.180 & -3.14 & 1.95 & 75.12 \\
\hline $5 f$ & 420.21 & 5 & 1 & 3.70 & 93.36 & 0 & 70.51 & 9 & 0 & 24 & 318.91 & 1.407 & -4.24 & 2.89 & 84.67 \\
\hline $5 g$ & 334.31 & 6 & 2 & 1.77 & 87.14 & 0 & 76.50 & 7 & 0 & 23 & 291.47 & 1.297 & -3.01 & 1.38 & 82.60 \\
\hline $5 h$ & 339.28 & 7 & 1 & 1.51 & 81.79 & 0 & 89.17 & 7 & 0 & 23 & 286.42 & 1.323 & -3.20 & 1.45 & 78.24 \\
\hline $5 i$ & 341.30 & 7 & 7 & 0.96 & 84.18 & 0 & 99.17 & 8 & 0 & 23 & 296.05 & 1.275 & -2.21 & 1.20 & 74.78 \\
\hline $5 j$ & 420.20 & 7 & 2 & 1.92 & 91.80 & 0 & 99.37 & 8 & 0 & 24 & 313.94 & 1.480 & -3.04 & 1.65 & 74.72 \\
\hline
\end{tabular}

${ }^{a} \mathrm{MW}$ : molecular weight; HB Don: hydrogen bond donors ( $\left.n \mathrm{ON}\right)$; HB Acc: hydrogen bond acceptors $(n \mathrm{OH} \mathrm{NH})$; $\log P: \log$ of octanol to water partition coefficient; MR: molecular refractivity $\left(\mathrm{cm}^{3} / \mathrm{mol}\right)$; Lip. Vio.: lipinski violations; TPSA: total polar surface area $(\AA)^{2}$; no. of RB: number of rotatable bonds; Veb. Vio.: Veber violations; no. of "H": number of hydrophobic atoms; V. Vol.: van der Waals volume; $\rho$ : density (gm/cc); $S$ : solubility; CLP: $\operatorname{clog} P$; and \% ABS: \% of absorption.

regulatory activity. Remarkably, they were bound to TYR597 with a binding energy of -8.1484 to $-7.3909 \mathrm{kcal} / \mathrm{mol}$ with a rational bond length of 1.9397-2.7589 $\AA$ in forming hydrogen bonds. Profoundly, compounds $\mathbf{5 a - j}$ formed hydrogen bonding with TYR597 as the amino hydrogen atom of the $\alpha$-aminophosphoryl group has been strongly bound to the phenolic oxygen atom present on the tyrosine; hence, here the compounds $\mathbf{5 a}-\mathbf{j}$ act as electron cloud acceptors in forming the hydrogen bond. This investigation unveils that GLN340 and TYR597 amino acids are strongly bound to $\mathbf{5 a - j}$ and are act as donors and acceptors, respectively, and responsible for the predicted in vitro activities.

2.5. ADMET Properties. The analysis of ADMET profiles for a library of molecules under scrutiny helps to figure out the physicochemical collaborations and evaluate their druglikeness properties. This sort of high-throughput screening assists in characterizing a lead one out of a large group in the captivated field of a target. ${ }^{63}$ This critical investigation had supported in predicting the pharmacokinetic effects of $5 \mathbf{a}-\mathbf{j}$ and to disclose the druglikeness properties. Among the ADMET properties, the human intestinal absorption designates transporting of the effective composites to the target cell tissues via blood stream and sustains their mutual interaction. During this the oral administration of a compound under study, its degree of absorption has been taken into account, which depends on its intrinsic bioavailability characteristics. In turnout, the absorbed quantity of the analyte is distributed to the muscles and then to other organs in self-circulation mode through extracellular sites. Then, the distribution of analyte drops down its plasma concentration autonomously and then metabolized; from there, such metabolites will be dispersed to the target sites by enzymatic redox reactions. In pharmacological perspectives, potentially distributed metabolites will work competently for cellular organisms, and on the other side, the inactive metabolites deactivate the controlled entity and moderate its possible effect in vivo; finally, the inert metabolites are inevitably emitted by kidneys. The analysis of the acquired ADMET profiles (Table 7) of $\mathbf{5 a - j}$ infers us about the in vivo blood-brain barrier (BBB) penetration potentiality ratio which is operational in the range of $0.4518-2.5729$ and authorizes their high central nervous system (CNS) significance and commends their greater permeability for its distribution in vivo. It is strengthened on the source that the in vitro Caco-2 cell permeability property is effective within 16.1225 to $21.7231 \mathrm{~nm} / \mathrm{s}$ range and establishes their insistent moderate permeability to bind with plasma proteins and to pierce into the $\mathrm{BBB}$ system. The in vitro plasma protein binding (PPB) affinity ranging from 90.6733 to $99.2126 \%$ empowers their robust binding ability to plasma proteins. The in vitro Maden Darby Canine kidney (MDCK) cell 
Table 9. Molecular Fingerprint Properties of $5 \mathrm{a}-\mathrm{j}^{a}$

\begin{tabular}{|c|c|c|c|c|c|c|c|c|c|c|c|c|c|}
\hline entry & $\begin{array}{l}\text { point } \\
\text { group }\end{array}$ & $\begin{array}{c}\text { H.F. } \\
(\mathrm{kcal} / \mathrm{mol})\end{array}$ & T.E. $(\mathrm{eV})$ & E.E. $(\mathrm{eV})$ & $\begin{array}{l}\text { C.C.R. } \\
(\mathrm{eV})\end{array}$ & G.N. & $\begin{array}{l}\text { dipole } \\
\text { (Debye) }\end{array}$ & $\begin{array}{l}\text { no. of } \\
\text { F.L. }\end{array}$ & $\begin{array}{l}\text { I.P. } \\
(\mathrm{eV})\end{array}$ & $\begin{array}{l}\text { H.E. } \\
(\mathrm{eV})\end{array}$ & $\begin{array}{l}\text { L.E. } \\
(\mathrm{eV})\end{array}$ & $\begin{array}{l}\text { C.A. } \\
\left(\AA^{2}\right)\end{array}$ & $\begin{array}{l}\text { C.V. } \\
\left(\AA^{3}\right)\end{array}$ \\
\hline $5 a$ & $\mathrm{C} 1$ & -106.66 & -4165.36 & -31020.65 & 26855.30 & 0.98 & 1.89 & 64 & 8.36 & -8.36 & 0.07 & 375.31 & 430.50 \\
\hline $5 b$ & $\mathrm{C} 1$ & -105.79 & -4165.32 & -31142.12 & 26976.79 & 0.94 & 1.84 & 64 & 8.14 & -8.14 & 0.30 & 372.69 & 431.76 \\
\hline $5 c$ & $\mathrm{C} 1$ & -209.24 & -4489.49 & -33075.83 & 28586.33 & 0.92 & 2.49 & 66 & 8.79 & -8.79 & -0.05 & 370.76 & 440.94 \\
\hline $5 d$ & $\mathrm{C} 1$ & -209.11 & -4823.17 & -35478.33 & 30655.16 & 0.99 & 2.09 & 69 & 8.91 & -8.91 & -0.24 & 386.63 & 463.71 \\
\hline $5 e$ & $\mathrm{C} 1$ & -241.18 & -5123.82 & -40651.74 & 35527.92 & 0.90 & 1.53 & 75 & 9.07 & -9.0 & -0.30 & 402.91 & 497.09 \\
\hline $5 f$ & $\mathrm{C} 1$ & -167.25 & -4487.54 & -30712.54 & 26224.99 & 0.97 & 1.97 & 63 & 9.17 & -9.17 & -0.60 & 365.74 & 429.05 \\
\hline $5 g$ & $\mathrm{C} 1$ & -96.74 & -3852.44 & -26907.70 & 23055.26 & 0.99 & 1.81 & 58 & 8.38 & -8.38 & 0.06 & 335.01 & 384.06 \\
\hline $5 h$ & $\mathrm{C} 1$ & -187.95 & -4147.75 & -27663.14 & 23515.38 & 0.91 & 1.84 & 59 & 8.86 & -8.86 & -0.20 & 330.80 & 375.71 \\
\hline $5 i$ & $\mathrm{C} 1$ & -202.23 & -4176.70 & -28679.19 & 24502.48 & 0.98 & 2.43 & 60 & 8.73 & -8.73 & 0.05 & 335.26 & 391.00 \\
\hline $5 j$ & $\mathrm{C} 1$ & -199.95 & -4510.28 & -30781.31 & 26271.03 & 0.95 & 0.82 & 63 & 9.09 & -9.09 & -0.38 & 357.86 & 417.55 \\
\hline
\end{tabular}

${ }^{a}$ H.F.: heat of formation; T.E.: total energy; E.E.: electronic energy; C.C.R: core-core repulsion; G.N.: gradient norm; F.L.: filled levels; I.P.: ionization potential; H.E.: HOMO energy; L.E.: LUMO energy; C.A.: COSMO area; and C.V.: COSMO volume.

Table 10. Bioactivity Scores, Drug Properties, and Toxicity Risks of $5 a-j^{a}$

\begin{tabular}{|c|c|c|c|c|c|c|c|c|c|c|c|c|}
\hline \multirow[b]{2}{*}{ entry } & \multicolumn{6}{|c|}{ bioactivity } & \multicolumn{2}{|c|}{ drug properties } & \multicolumn{4}{|c|}{ toxicity risks } \\
\hline & GPCRL & ICM & $\mathrm{KI}$ & NRL & PI & EI & drug-likeness & drug score & Mut & Tum & Irrit & R.E. \\
\hline $5 a$ & -0.20 & 0.14 & -0.20 & -0.46 & 0.01 & 0.11 & -32.76 & 0.42 & green & green & green & green \\
\hline $5 b$ & -0.24 & 0.07 & -0.27 & -0.33 & 0.02 & 0.10 & -34.08 & 0.08 & green & green & green & green \\
\hline $5 c$ & -0.46 & 0.01 & -0.47 & -0.51 & -0.07 & 0.02 & -33.04 & 0.43 & green & green & green & green \\
\hline $5 d$ & -0.64 & -0.12 & -0.56 & -0.68 & -0.23 & -0.11 & -34.72 & 0.33 & green & green & green & green \\
\hline $5 e$ & -0.45 & -0.04 & -0.44 & -0.59 & -0.09 & -0.03 & -30.14 & 0.44 & green & green & green & green \\
\hline $5 f$ & -0.49 & -0.04 & -0.46 & -0.62 & -0.18 & -0.08 & -38.50 & 0.34 & green & green & green & green \\
\hline $5 g$ & -0.21 & 0.20 & -0.29 & -0.58 & 0.01 & 0.15 & -25.33 & 0.16 & green & green & green & green \\
\hline $5 \mathrm{~h}$ & -0.47 & -0.01 & -0.65 & -0.75 & -0.06 & 0.10 & -25.97 & 0.15 & green & green & green & green \\
\hline $5 i$ & -0.47 & 0.06 & -0.57 & -0.61 & -0.07 & 0.06 & -25.68 & 0.16 & green & green & green & green \\
\hline $5 \mathbf{j}$ & -0.66 & -0.07 & -0.66 & -0.79 & -0.22 & -0.08 & -27.42 & 0.14 & green & green & green & green \\
\hline
\end{tabular}

${ }^{a}$ GPCRL: G protein-coupled receptor ligand; ICM: ion channel modulator; KI: kinase inhibitor; NRL: nuclear receptor ligand; PI: protease inhibitor; EI: enzyme inhibitor; Mut: mutagenic; Tum: tumorigenic; Irrit: irritant; R.E.: reproductive effect; green: green color indicates drugconform behavior.

permeability readings ranging from 27.9760 to $191.0100 \mathrm{~nm} / \mathrm{s}$ discloses them as worthy permeable. In the same way, the human intestinal absorption (\% HIA) in the range of 86.9710-97.2754 ratio promises the interactions of $\mathbf{5 a - j}$ with suitable species of the anticipating target domains. The negative sign of toxicity properties of $5 \mathbf{a}-\mathbf{j}$ assures them as safer and nontoxic drugs. In summary, this analysis has revealed the physicochemical interactions and druglikeness properties of $\mathbf{5 a} \mathbf{a} \mathbf{j}$.

2.6. QSAR Studies. The results obtained from in silico molecular descriptor properties (Table 8) designates that compounds $\mathbf{5 a}-\mathbf{j}$ are designed to obey the properties and their molecular weights ranging from 334.31 to 448.25 (less than $500 \mathrm{Da}$ ) approves the same. Similarly, they have been validated with $\log P$ values in the range of $4.24-0.96$ (less than 5) suggesting their good permeability through cell membranes. Likewise in the line of Lipinski's rule of five, the number of hydrogen bond donors $<5$ and acceptors $<10$ are also validated in all molecules that were synthesized. Similarly, the molecular refractivity ranging from 81.79 to $126.18 \mathrm{~cm}^{3} / \mathrm{mol}$ has also obeyed the valid range, that is, $40-130 \mathrm{~cm}^{3} / \mathrm{mol}$.

Hence, ascertained compounds $\mathbf{5 a}-\mathbf{j}$ are following the Lipinski rule of five, and all of them are significantly orally active drugs with worthy druglikeness properties. Furthermore, the total polar surface area is precised by the total effect of all polar atoms such as oxygen, nitrogen, and attached hydrogens; ${ }^{64}$ for instance, compounds $\mathbf{5 a} \mathbf{a} \mathbf{j}$ are also in the range of 60.71-99.97 $\AA^{2}$, which are ultimately less than $140 \AA^{2}$, and are also satisfying the Veber rule. Henceforth, compounds $\mathbf{5 a - j}$ are assessed as they can be easily diffused, absorbed, and transported in the systems to which they are exposed. At this juncture, TPSA is highly interrelated with the hydrogen bonding of a compound and is accompanied with the transport properties of that drug across membranes and the correlation of $\mathrm{BBB}$ for the intestinal crossing. Compounds with TPSA $\leq 160 \AA^{2}$ have been identified as good intestinal absorption compounds with BBB penetrability $\leq 60 \AA^{2}$ as BBB-penetrable and CNS-active agents. ${ }^{65}$ TPSA for the scrutinized sequences all the offshoots have been identified as the best intestinal absorbing ones. Similarly, the number of rotatable bonds among all the compounds is identified with a range of 7-12, which is according to the Veber rule, and eventually, they are also obeying the Veber's rule and established themselves as orally administrable drugs. Furthermore, the percentage of absorption in the range of 79.23-88.06, density ranging from 1.246 to $1.480 \mathrm{gm} / \mathrm{cc}$, solubility in the range of -2.21 to -4.24 , van der Waals volume ranging from 286.42 to 400.65 $\AA^{3}$, and clog $P$ ranging from 1.20 to 3.19 establish compounds $\mathbf{5 a}-\mathbf{j}$ drug-like compounds and are significantly safer. These properties helped a lot in considering their physicochemical interactions against the target entities and eventually helped in deciding the drug potentialities that are associated by the bioactivity and toxicity risks studies.

The synthesized molecules $\mathbf{5} \mathbf{a}-\mathbf{j}$ are identified with the fingerprint properties (Table 9) as having all of them are having the $\mathrm{C} 1$ point group of symmetry elements in them and 
heat of formation is identified within the range of -96.74 to $-241.18 \mathrm{kcal} / \mathrm{mol}$, total energy ranges from -3852.44 to $-5123.82 \mathrm{eV}$, electronic energy ranges from -26907.7 to $-40651.74 \mathrm{eV}$, and core-core repulsion energy ranges from 23055.26 to $35527.92 \mathrm{eV}$. Similarly, the gradient norm is identified in the ranges of values from 0.90 to 0.99 , whereas the dipole difference is identified with $0.82-2.49$ debye. The filled levels were identified with 58-75 units, and the ionization potential values are identified from 8.14 to $9.17 \mathrm{eV}$. Similarly, highest occupied molecular orbital (HOMO) and lowest unoccupied molecular orbital (LUMO) energies are identified from -8.14 to $-9.17 \mathrm{eV}$ and from -0.6 to $0.3 \mathrm{eV}$, respectively. Similarly, the Cosmo area and Cosmo volumes are identified within the range of 330.80-402.91 $\AA^{2}$ and 375.71-497.09 $\AA^{3}$, respectively. All these predicted values confirm that the synthesized molecules are correlating with the potential limits of safer drugs and pharmaceuticals, and hence, in complementary perspectives of the molecular descriptors, they are obeying the QSAR properties.

2.7. Bioactivity and Toxicity Risk Studies. The study of bioactivity and toxicity risk properties of $\mathbf{5 a - j}$ (Table 10) inferred the bioactivity properties such as GPCRL (GPCR ligand property), ICM (ion channel modulator), KI (kinase inhibitor), NRL (nuclear receptor ligand) interactions, PI (protease inhibitor) and EI (enzyme inhibitor) interactions, and drug properties (druglikeness and drug scores), which have ascertained them as nontoxic and potential molecules. Prediction of these properties by Molinspiration software had comprehensively helped to assess the cheminformatics of $\mathbf{5 a - j}$ by relating with in vitro and in vivo results based on functional group similarity. The results of toxicity risk study supporting $\mathbf{5} \mathbf{a}-\mathbf{j}$ as safer compounds as they are encompassed with no risks of tumorigenicity, mutagenicity, irritant and are showing no effect on the reproductive system and conformed their drug-like behavior. The positive magnitude of druglikeness represents most of the fragments that are the part of commercial drug molecules; however, many compounds signify the negative magnitudes. ${ }^{66}$ Another important factor that infers about the association of a substance from the administering site to the blood stream is solubility, and good solubility leads to good absorption. ${ }^{67}$ Similarly, drug score is considered as a harmonizing parameter that wholly represents $\operatorname{clog} P$, druglikeness, $\log S$, toxicity risks, and molecular weight and accounted to decide the molecule's inclusive potential to denote a drug. Eventually, it is identified that all the synthesized analogues $\mathbf{5 a - j}$ showed higher scores (Table 10).

2.8. Structure-Activity Relationship Studies. The molecular docking studies of $\mathbf{5 a}-\mathbf{j}$ have well established the structure-activity relationship for them as molecules were intensely bound to glutamine (GLN340) located on chain C of 1DNU protein. Specifically, hydrogen bonding with GLN340 is identified as such the oxygen atom of the phosphoryl group has been strongly bound to the amino hydrogen atom of the amide bond present on the glutamine and is responsible for the antioxidant activity.

Similarly, molecules are strongly bound to tyrosine (TYR597) located on chain A of 4ME7 protein. Specifically, hydrogen bonding with TYR597 is identified as such the amino hydrogen atom of the $\alpha$-aminophosphoryl group has been strongly bound to the phenolic oxygen atom present on the tyrosine and is responsible for the antioxidant activity (Figure 5). Moreover, the oxidative stress comprehends the pathogenesis of neurodegenerative diseases triggered by the

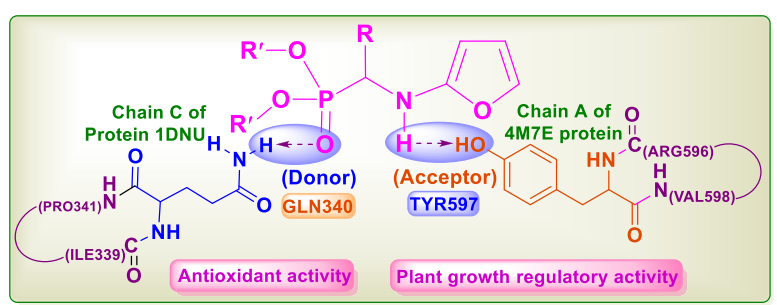

Figure 5. Structure-activity relationship of $\mathbf{5 a - j}$.

excess quantity of reactive oxygen species created in vivo by uneven biochemical disorders and which again causes damage of neuronal cells and their death. ${ }^{68-71}$ In relation to this, the title compounds are identified as good BBB-penetrable compounds; they can be considered as neuroprotective antioxidants with CNS-active potentiality as the neuroprotective property is determined with $\mathrm{BBB}$ penetration thresholds.

\section{CONCLUSIONS}

Novel $\alpha$-furfuryl-2-alkylaminophosphonates $(\mathbf{5 a} \mathbf{a} \mathbf{j})$ were successfully synthesized with the aid of $\mathrm{SiO}_{2}-\mathrm{I}_{2}$, an ecofriendly catalyst. Their antioxidant properties were studied by $\mathrm{DPPH}$ and $\mathrm{H}_{2} \mathrm{O}_{2}$ radical scavenging assays. The plant growth regulatory activity in terms of growth of root length and shoot length was studied and observed that compounds $\mathbf{5 e}, \mathbf{5 c}$, and $5 \mathbf{i}$ were identified with potential activity and comparable to the standards. The additional studies such as ADMET, QSAR, molecular docking, and bioactivity and toxicity risk have been well correlating with the results predicted in vitro. The complementary consideration of all the studies has supported the synthesized compounds as potential antioxidants and plant growth regulators with potential CNS-active neuroprotective antioxidant activity.

\section{EXPERIMENTAL SECTION}

4.1. General. Chemicals are acquired from Sigma-Aldrich, solvents were distilled before use, and the reactions were performed on a CATA-4R (Catalyst System) scientific microwave instrument. Thin-layer chromatography (TLC) analysis has been performed on silica gel-G-coated aluminum sheets as procured from Merck; the analyte mobilities were visualized under UV light, iodine absorption, and ninhydrin solution. ${ }^{1} \mathrm{H}$ and ${ }^{13} \mathrm{C}$ NMR and spectral studies were performed on a Bruker $400 \mathrm{MHz}$ spectrometer, and the spectra were recorded in deuterated chloroform $\left(\mathrm{CDCl}_{3}\right)$ by using tetramethylsilane (TMS) as an internal reference standard.

Infrared (IR) spectra were recorded on a Bruker Alpa-ECOATR-FTIR (attenuated total reflection Fourier transform infrared) interferometer by using a single reflection sampling module equipped with a zinc selenide ( $\mathrm{ZNSe}$ ) crystal, and the readings were expressed in reciprocals of centimeter $\left(\mathrm{cm}^{-1}\right)$. Mass spectra were recorded by using an Agilent-MS spectrometer.

4.2. Chemistry. Synthesis of aminophosphonates $(\mathbf{5 a}-\mathbf{j})$ has been achieved from the reaction of a mixture of carbonyl derivatives $(1.0 \mathrm{mmol})$, furfurylamine $(1 \mathrm{mmol})$, and diethyl/ dimethyl hydrogen phosphite $(1.0 \mathrm{mmol})$ by using $\mathrm{SiO}_{2}-\mathrm{I}_{2}$ $(10 \mathrm{~mol} \%)$ catalyst by irradiating under microwave at $600 \mathrm{~W}$ and $40{ }^{\circ} \mathrm{C}$ for $15-25 \mathrm{~min}$. The reaction progress was scrutinized by TLC for the completion of the reaction and 
then $25 \mathrm{~mL}$ of ethyl acetate was added to the crude content and filtered, followed by washing with ethyl acetate $(2 \times 10$ $\mathrm{mL}$ ). Then, the solvent contents were evaporated by a rotary evaporation process. The crude compound was purified, and the pure product was collected by column chromatography and characterized by spectral and elemental analysis.

4.2.1. Diethyl (((Furan-2-ylmethyl)amino)(1H-indol-3-yl)methyl)phosphonate (5a). Brown liquid, 92\% yield (334.7 $\mathrm{mg})$; FT-IR (ZnSe): $v_{\max } 3215,2977,2924,1444,1432,1213$, 1019, 953, 734; ${ }^{1} \mathrm{H}$ NMR (400 MHz, $\mathrm{CDCl}_{3} / \mathrm{TMS}$ ): $\delta 10.08$ (br s, $1 \mathrm{H}), 7.71-7.69\left(d, J_{\mathrm{HH}}=7.72 \mathrm{~Hz}, 1 \mathrm{H}\right), 7.38-7.7 .35(m$, $2 \mathrm{H}), 7.24(s, 1 \mathrm{H}), 7.17-7.08(m, 2 \mathrm{H}), 6.29(s, 1 \mathrm{H}), 6.09(s$, $1 \mathrm{H}), 4.46\left(d, J_{H H}=17.4 \mathrm{~Hz}, 1 \mathrm{H}\right), 4.16-4.09(m, 2 \mathrm{H}), 4.00-$ $3.95(m, 1 \mathrm{H}), 3.89\left(d, J_{H H}=14.56,1 \mathrm{H}\right) .3 .81-3.74(m, 1 \mathrm{H})$, $3.72-3.68\left(d, J_{H H}=14.56,1 \mathrm{H}\right), 3.19(b r s, 1 \mathrm{H}), 1.31-1.27(m$, $3 \mathrm{H}), 1.09-1.05(m, 3 \mathrm{H}) ;{ }^{13} \mathrm{C} \mathrm{NMR}\left(100 \mathrm{MHz}, \mathrm{CDCl}_{3} /\right.$ TMS): $\delta 153.05,142.07,136.49,126.96,124.99,121.79$, $119.20,111.74,110.20,108.38,107.83,77.39,76.91,62.98$, $52.10,50.48,16.17$; HRMS (ESI) $\mathrm{m} / z$ calcd for $\mathrm{C}_{18} \mathrm{H}_{23} \mathrm{~N}_{2} \mathrm{O}_{4} \mathrm{P}^{+}(\mathrm{M}+\mathrm{H})$, 362.1395; found, 362.1392 .

4.2.2. Diethyl (((Furan-2-ylmethyl)amino)(pyren-4-yl)methyl)phosphonate (5b). Dark brown liquid, 90\% yield (402.3 mg); FT-IR ( $\mathrm{ZnSe}): v_{\max } 3318,2981,2920,1678$, 1234, 1017, 954, 730; ${ }^{1} \mathrm{H}$ NMR (400 $\left.\mathrm{MHz}, \mathrm{CDCl}_{3}\right): 8.49(s$, $1 \mathrm{H}), 8.34(s, 1 \mathrm{H}), 8.28(d, J=7.2 \mathrm{~Hz}, 1 \mathrm{H}), 8.20-8.12(m$, $3 \mathrm{H}), 8.05(d, J=9.2 \mathrm{~Hz}, 2 \mathrm{H}), 8.02-7.93(m, 1 \mathrm{H}), 7.37(s$, $1 \mathrm{H}), 7.29(s, 1 \mathrm{H}), 6.28(s, 1 \mathrm{H}), 5.99(s, 1 \mathrm{H}), 5.33(d, J=19.6$ $\mathrm{Hz}, 1 \mathrm{H}), 4.17-4.03(m, 2 \mathrm{H}), 3.90(d, J=14.0 \mathrm{~Hz}, 2 \mathrm{H}), 3.70$ $(d d, J=15.5,7.4 \mathrm{~Hz}, 1 \mathrm{H}), 3.60(d, J=14.7 \mathrm{~Hz}, 1 \mathrm{H}), 3.22(s$, $1 \mathrm{H}), 1.27(\mathrm{t}, J=6.2 \mathrm{~Hz}, 3 \mathrm{H}), 0.99(t, J=6.6 \mathrm{~Hz}, 3 \mathrm{H}) ;{ }^{13} \mathrm{C}$ NMR $\left(101 \mathrm{MHz}, \mathrm{CDCl}_{3}\right): \delta 152.80,142.20,131.37,130.97$, $130.67,130.01,128.90,127.63,125.51,124.80,124.75,110.20$, 108.12, 77.64, 77.32, 77.01, 63.78, 62.99, 43.70, 34.88, 16.50; HRMS (ESI) $m / z$ calcd for $\mathrm{C}_{26} \mathrm{H}_{26} \mathrm{NO}_{4} \mathrm{P}^{+}(\mathrm{M}+\mathrm{H}), 447.1599$; found, 447.1598 .

4.2.3. Diethyl (((Furan-2-ylmethyl)amino)(4-hydroxy-3methoxyphenyl)methyl)phosphonate (5c). Yellow liquid, $95 \%$ yield (349.8 mg), FT-IR ( $\mathrm{ZnSe}): v_{\max } 3184,2980$, 2920, 1514, 1211, 1021, 953, 738; ${ }^{1} \mathrm{H}$ NMR (400 MHz, $\left.\mathrm{CDCl}_{3}\right): \delta 7.34(d, J=1.0 \mathrm{~Hz}, 1 \mathrm{H}), 7.03(s, 1 \mathrm{H}), 6.86(d, J=$ $2.1 \mathrm{~Hz}, 2 \mathrm{H}), 6.32-6.26(m, 1 \mathrm{H}), 6.09(d, J=2.5 \mathrm{~Hz}, 1 \mathrm{H})$, $4.08-4.01(m, 2 \mathrm{H}), 4.00-3.92(m, 2 \mathrm{H}), 3.88(d, J=3.2 \mathrm{~Hz}$, $3 \mathrm{H}), 3.87-3.83(\mathrm{~m}, 1 \mathrm{H}), 3.82-3.76(\mathrm{~m}, 1 \mathrm{H}), 3.56(d, J=14.6$ $\mathrm{Hz}, 1 \mathrm{H}), 1.27(t, J=7.1 \mathrm{~Hz}, 3 \mathrm{H}), 1.17(t, J=7.1 \mathrm{~Hz}, 3 \mathrm{H}) ;{ }^{13} \mathrm{C}$ NMR (101 MHz, $\left.\mathrm{CDCl}_{3}\right): \delta 152.84,146.98,145.75,142.01$, $126.34,122.03,114.45,111.07,110.09,107.73,77.41,77.09$, 76.77, 62.94, 59.59, 58.04, 55.95, 43.49, 16.32; HRMS (ESI) $m / z$ calcd for $\mathrm{C}_{17} \mathrm{H}_{24} \mathrm{NO}_{6} \mathrm{P}^{+}(\mathrm{M}+\mathrm{H}), 369.1341$; found, 362.1344 .

4.2.4. Diethyl ((3-Bromo-4-hydroxy-5-methoxyphenyl) ((Furan-2 ylmethyl)amino) methyl) Phosphonate (5d). Orange red liquid, $89 \%$ yield $(398.7 \mathrm{mg})$, FT-IR ( $\mathrm{ZnSe})$ : $v_{\max } 3125,2980,1495,1424,1278,1231,1156,1026,728 ;{ }^{1} \mathrm{H}$ $\operatorname{NMR}\left(400 \mathrm{MHz}, \mathrm{CDCl}_{3}\right): \delta 9.73(s, 1 \mathrm{H}), 7.35(d, J=1.3 \mathrm{~Hz}$, $2 \mathrm{H}), 7.12(d, J=1.9 \mathrm{~Hz}, 2 \mathrm{H}), 6.99(d, J=1.8 \mathrm{~Hz}, 2 \mathrm{H}), 6.30$ $(d, J=1.7 \mathrm{~Hz}, 2 \mathrm{H}), 6.10(\mathrm{~s}, 2 \mathrm{H}), 4.11-3.95(\mathrm{~m}, 8 \mathrm{H}), 3.89(d$, $J=2.0 \mathrm{~Hz}, 10 \mathrm{H}), 3.80(d, J=15.0 \mathrm{~Hz}, 2 \mathrm{H}), 3.56(d, J=14.7$ $\mathrm{Hz}, 2 \mathrm{H}), 3.04-2.94(\mathrm{~m}, 2 \mathrm{H}), 1.27(t, J=8.9 \mathrm{~Hz}, 6 \mathrm{H}), 1.21(t$, $J=8.1 \mathrm{~Hz}, 6 \mathrm{H}) ;{ }^{13} \mathrm{C} \mathrm{NMR}\left(101 \mathrm{MHz}, \mathrm{CDCl}_{3}\right): \delta 155.58$, $150.54,146.09,145.12,113.16,110.89,80.44,80.12,79.80$, 66.34, 65.89, 62.25, 60.71, 59.43, 46.47, 19.38, 11.57; HRMS (ESI) $m / z$ calcd for $\mathrm{C}_{17} \mathrm{H}_{23} \mathrm{BrNO}_{6} \mathrm{P}^{+}(\mathrm{M}+\mathrm{H}), 447.0446$; found, 447.0448 .
4.2.5. Diethyl ((Furan-2-ylmethyl)amino)(3,4,5trimethoxyphenyl)methyl)phosphonate (5e). Pale yellow liquid, $96 \%$ yield $(396.6 \mathrm{mg})$; FT-IR ( $\mathrm{ZnSe}): v_{\max }$ 3216, 2991, 2933, 1524, 1221, 1037, 956, 735; ${ }^{1} \mathrm{H}$ NMR (400 MHz, $\left.\mathrm{CDCl}_{3}\right): \delta 7.33(s, 2 \mathrm{H}), 6.67(d, J=2.2 \mathrm{~Hz}, 3 \mathrm{H}), 6.28(d, J=$ $2.4 \mathrm{~Hz}, 2 \mathrm{H}), 6.09(d, J=3.3 \mathrm{~Hz}, 2 \mathrm{H}), 4.10-3.95(m, 8 \mathrm{H})$, $3.95-3.90(m, 3 \mathrm{H}), 3.90-3.81(m, 20 \mathrm{H}), 3.78(s, 2 \mathrm{H}), 1.26(t$, $J=7.1 \mathrm{~Hz}, 7 \mathrm{H}), 1.18(t, J=7.0 \mathrm{~Hz}, 7 \mathrm{H}) ;{ }^{13} \mathrm{C} \mathrm{NMR}(100$ $\left.\mathrm{MHz}, \mathrm{CDCl}_{3}\right): \delta 153.19,152.78,142.03,130.59,110.10$, 107.75, 105.67, 99.99, 77.43, 77.12, 76.80, 62.92, 60.81, 60.13, 58.59 , 56.13, 43.50, 16.26; HRMS (ESI) $m / z$ calcd for $\mathrm{C}_{19} \mathrm{H}_{28} \mathrm{NO}_{7} \mathrm{P}^{+}(\mathrm{M}+\mathrm{H})$, 413.1603; found, 413.1601.

4.2.6. Diethyl ((5-Bromo-2-fluorophenyl)((furan-2ylmethyl)amino)methyl)phosphonate (5f). Orange red liquid, $85 \%$ yield $(357.2 \mathrm{mg})$; FT-IR $(\mathrm{ZnSe}): v_{\max } 3306$, 2982, 1477, 1237, 1021, 958, 805, 731; ${ }^{1} \mathrm{H}$ NMR (400 MHz, $\left.\mathrm{CDCl}_{3}\right): \delta 7.73-7.69(\mathrm{~m}, 1 \mathrm{H}), 7.33(d d t, J=8.9,4.5,2.3 \mathrm{~Hz}$, $1 \mathrm{H}), 7.29(d, J=1.7 \mathrm{~Hz}, 1 \mathrm{H}), 6.90(t, J=9.1 \mathrm{~Hz}, 1 \mathrm{H}), 6.22$ $(d d, J=3.1,1.9 \mathrm{~Hz}, 1 \mathrm{H}), 6.07(d, J=3.1 \mathrm{~Hz}, 1 \mathrm{H}), 4.38(d, J=$ $20.3 \mathrm{~Hz}, 1 \mathrm{H}), 4.13-4.04(m, 2 \mathrm{H}), 3.98(d d d, J=12.6,7.7,5.8$ $\mathrm{Hz}, 2 \mathrm{H}), 3.76(d, J=14.6 \mathrm{~Hz}, 1 \mathrm{H}), 3.55(d, J=14.6 \mathrm{~Hz}, 1 \mathrm{H})$, $1.25(t, J=7.1 \mathrm{~Hz}, 3 \mathrm{H}), 1.16(t, J=7.1 \mathrm{~Hz}, 3 \mathrm{H}) ;{ }^{13} \mathrm{C} \mathrm{NMR}$ $\left(100 \mathrm{MHz}, \mathrm{CDCl}_{3}\right): \delta 161.38,158.91,152.21,142.13,132.26$, $125.63,117.00,110.12,107.91,99.99,77.50,77.18,76.86$, 63.06, 51.97, 50.40, 43.97, 16.20; HRMS (ESI) $\mathrm{m} / z$ calcd for $\mathrm{C}_{16} \mathrm{H}_{20} \mathrm{BrFNO}_{4} \mathrm{P}^{+}(\mathrm{M}+\mathrm{H}), 419.0297$; found, 419.0296 .

4.2.7. Dimethyl (((Furan-2-ylmethyl)amino) $(1 \mathrm{H}$-indol-3yl)methyl)phosphonate (5g). Orange yellow solid, 90\% yield (301 mg); FT-IR (ZnSe): $v_{\max } 3168,2923,2852,1646,1449$, $1185,1037,731,{ }^{1} \mathrm{H}$ NMR $\left(400 \mathrm{MHz}, \mathrm{CDCl}_{3}\right): \delta 9.49(d, J=$ $23.7 \mathrm{~Hz}, 1 \mathrm{H}), 7.69-7.60(m, 1 \mathrm{H}), 7.42-7.35(m, 2 \mathrm{H}), 7.24-$ $7.10(m, 3 \mathrm{H}), 6.38-6.22(m, 2 \mathrm{H}), 6.10(d, J=3.2 \mathrm{~Hz}, 1 \mathrm{H})$, $4.47(d, J=17.4 \mathrm{~Hz}, 1 \mathrm{H}), 3.96(d, J=10.5 \mathrm{~Hz}, 1 \mathrm{H}), 3.76(d, J$ $=10.5 \mathrm{~Hz}, 3 \mathrm{H}), 3.53(d, J=10.4 \mathrm{~Hz}, 3 \mathrm{H}) ;{ }^{13} \mathrm{C} \mathrm{NMR}(101$ $\left.\mathrm{MHz}, \mathrm{CDCl}_{3}\right): \delta 152.95,142.04,136.33,126.85,122.10$, $119.71,119.13,118.66,111.66,110.15,108.69,107.85,104.25$, 100.00, 77.40, 77.09, 76.77, 53.46, 43.61; HRMS (ESI) $m / z$ calcd for $\mathrm{C}_{16} \mathrm{H}_{19} \mathrm{~N}_{2} \mathrm{O}_{4} \mathrm{P}^{+}(\mathrm{M}+\mathrm{H}), 334.1082$; found, 334.1078 .

4.2.8. Dimethyl (benzo[d][1,3]dioxol-5-yl((furan-2ylmethyl)amino)methyl)phosphonate (5h). Pale yellow solid, $83 \%$ yield $(281.7 \mathrm{mg})$; FT-IR $(\mathrm{ZnSe}): v_{\max }$ 3218, 2945, 1620, 1232, 1025, 820, 746; ${ }^{1} \mathrm{H}$ NMR (400 MHz, $\left.\mathrm{CDCl}_{3}\right): \delta 7.24(d, J=5.9 \mathrm{~Hz}, 2 \mathrm{H}), 6.85(d, J=1.5 \mathrm{~Hz}, 2 \mathrm{H})$, $6.71(d d, J=20.1,12.2 \mathrm{~Hz}, 4 \mathrm{H}), 6.14(d, J=1.8 \mathrm{~Hz}, 2 \mathrm{H}), 5.98$ $(t, J=9.9 \mathrm{~Hz}, 2 \mathrm{H}), 5.79(s, 4 \mathrm{H}), 4.86(d, J=87.0 \mathrm{~Hz}, 1 \mathrm{H})$, $3.85(d, J=19.0 \mathrm{~Hz}, 2 \mathrm{H}), 3.58(s, 6 \mathrm{H}), 3.47(s, 6 \mathrm{H}) ;{ }^{13} \mathrm{C} \mathrm{NMR}$ $\left(100 \mathrm{MHz}, \mathrm{CDCl}_{3}\right): \delta 152.57,147.92,147.44,141.99,128.49$, 122.28, 110.04, 108.62, 108.15, 107.68, 101.11, 59.08, 57.53, $53.42,43.10$; HRMS (ESI) $m / z$ calcd for $\mathrm{C}_{14} \mathrm{H}_{18} \mathrm{NO}_{6} \mathrm{P}^{+}(\mathrm{M}+$ $\mathrm{H}), 339.0872$; found, 339.0874 .

4.2.9. Dimethyl (((Furan-2-ylmethyl)amino)(4-hydroxy-3methoxyphenyl)methyl)phosphonate (5i). Yellow solid, 93\% yield $(317.2 \mathrm{mg})$; FT-IR $(\mathrm{ZnSe}): v_{\max } 3428,3168,2942,1693$, 1497, 1178, 1032, 732; ${ }^{1} \mathrm{H}$ NMR (400 MHz, $\mathrm{CDCl}_{3}$ ): $\delta 7.28$ $(d, J=4.6 \mathrm{~Hz}, 2 \mathrm{H}), 7.04(s, 1 \mathrm{H}), 6.93(s, 1 \mathrm{H}), 6.22(d, J=1.3$ $\mathrm{Hz}, 1 \mathrm{H}), 6.04(s, 1 \mathrm{H}), 3.90(d, J=18.9 \mathrm{~Hz}, 1 \mathrm{H}), 3.79(s, 3 \mathrm{H})$, $3.74(d, J=14.5 \mathrm{~Hz}, 2 \mathrm{H}), 3.67(d, J=10.6 \mathrm{~Hz}, 3 \mathrm{H}), 3.55(d, J$ $=10.5 \mathrm{~Hz}, 3 \mathrm{H}) ;{ }^{13} \mathrm{C}$ NMR $\left(100 \mathrm{MHz}, \mathrm{CDCl}_{3}\right): \delta 152.31$, 147.92, 143.47, 142.14, 126.81, 124.91, 110.15, 108.57, 107.97, $58.69,57.13,56.35,53.80,53.65,43.37$; HRMS (ESI) $\mathrm{m} / z$ calcd for $\mathrm{C}_{15} \mathrm{H}_{20} \mathrm{NO}_{6} \mathrm{P}^{+}(\mathrm{M}+\mathrm{H})$, 341.1028; found, 341.1026.

4.2.10. Dimethyl((3-bromo-4-hydroxy-5-methoxyphenyl)((furan-2-ylmethyl)amino)methyl)phosphonate (5j). Orange 
red solid, $85 \%$ yield $(357.1 \mathrm{mg})$; FT-IR $(\mathrm{ZnSe}): v_{\max } 3373$, $3113,2949,1603,1515,1455,1203,1029,743 ;{ }^{1} \mathrm{H}$ NMR (400 $\left.\mathrm{MHz}, \mathrm{CDCl}_{3}\right): \delta 7.24(d, J=7.6 \mathrm{~Hz}, 1 \mathrm{H}), 6.92(s, 1 \mathrm{H}), 6.83-$ $6.68(m, 2 \mathrm{H}), 6.17(d, J=5.1 \mathrm{~Hz}, 1 \mathrm{H}), 6.00(d, J=4.9 \mathrm{~Hz}$, $1 \mathrm{H}), 3.90(\mathrm{dd}, J=18.6,7.3 \mathrm{~Hz}, 1 \mathrm{H}), 3.76-3.33(\mathrm{~m}, 11 \mathrm{H}),{ }^{13} \mathrm{C}$ NMR $\left(100 \mathrm{MHz} \mathrm{CDCl}_{3}\right): \delta 152.55,147.49,146.23,142.02$, 125.49, 121.76, 121.70, 115.01, 111.28, 110.07, 107.79, 77.72, 77.41, 77.05, 59.00, 57.45, 55.80, 53.66, 43.08; HRMS (ESI) $m / z$ calcd for $\mathrm{C}_{15} \mathrm{H}_{19} \mathrm{BrNO}_{6} \mathrm{P}^{+}(\mathrm{M}+\mathrm{H}), 419.0133$; found, 419.0131 .

4.3. Antioxidant Activity. 4.3.1. DPPH Radical Scavenging Activity. In practice, the electron donation capacity or hydrogen atom donation ability of a compound is confirmed from the bleaching ability of purple color of methanolic DPPH solution to colorless. In this spectrophotometric study, $1 \mathrm{~mL}$ of the test sample of compounds that are to be screened for antioxidant activity with different concentrations (50,100, and $200 \mu \mathrm{g} / \mathrm{mL}$ ) was prepared and added to $4 \mathrm{~mL}$ of $0.004 \%(\mathrm{w} / \mathrm{v})$ methanolic DPPH solutions. ${ }^{72-76}$ Then, the analytical mixture was mixed thoroughly for $1 \mathrm{~min}$ and then incubated at room temperature for a period of $30 \mathrm{~min}$. After completion of incubation process, the absorbance of all the test samples was measured at $517 \mathrm{~nm}$ and was referenced to ascorbic acid reference standards. Finally, DPPH radical scavenging activity was obtained from the following equation.

$$
\% \text { of inhibition }=\frac{\left[\left(A_{\text {control }}-A_{\text {test }}\right)\right]}{\left(A_{\text {control }}\right)} \times 100
$$

4.3.2. $\mathrm{H}_{2} \mathrm{O}_{2}$ Radical Scavenging Activity. To the $1 \mathrm{~mL}$ test solution of different concentrations $(50,100$, and $200 \mu \mathrm{g} / \mathrm{mL})$ of the synthesized compounds of the study were added with $3.75 \mathrm{mM}$ of deoxyribose, $1.0 \mathrm{mM}$ of $\mathrm{H}_{2} \mathrm{O}_{2}, 20 \mathrm{mM}$ of potassium phosphate buffer $(7.4 \mathrm{pH}), 0.1 \mathrm{mM}$ of $\mathrm{FeCl}_{3}$, and $0.1 \mathrm{mM}$ of EDTA and incubated for a period of $1 \mathrm{~h}$ at $37{ }^{\circ} \mathrm{C}$ temperature in a water bath. The degree of degradation of deoxyribose was measured by adding thiobarbituric acid (1.0\%) and trichloroacetic acid (2.0\%) and heating them in a water bath at $100{ }^{\circ} \mathrm{C}$ for a period of $20 \mathrm{~min}$. Eventually, the absorbance of the resulting test solutions was obtained spectrophotometrically at $532 \mathrm{~nm}$ from the following equation.

$$
\% \text { of inhibition }=\frac{\left[\left(A_{\text {control }}-A_{\text {test }}\right)\right]}{\left(A_{\text {control }}\right)} \times 100
$$

4.4. Plant Growth Regulatory Activity. Seeds were germinated at $25{ }^{\circ} \mathrm{C}$ for $48 \mathrm{~h}$ in $12 \mathrm{~h}$ light and $12 \mathrm{~h}$ darkness. Groups of 50 uniform well-sterilized seedlings were transferred to $10 \mathrm{~cm}$ Petri dishes that are outlined with two discs of Whatman no. 1 filter paper wetted with $2 \mathrm{~mL}$ of $0.001 \mathrm{M}$ aqueous methanol (control) and $2 \mathrm{~mL}$ of solutions of the test compounds $(5 \mathbf{a}-\mathbf{j})$ at 50 and $100 \mathrm{ppm}$ concentrations. The plants were grown in simultaneous $16 \mathrm{~h}$ light and $8 \mathrm{~h}$ dark conditions at $25 \pm 2{ }^{\circ} \mathrm{C}$ for $48 \mathrm{~h}$ and the lengths of roots and stem were measured. The results are presented as the average increase or decrease in root length and shoot length compared with the control. Each experiment was repeated three times.

4.5. Molecular Docking Studies. The mechanistic inhibition of propagating $\mathrm{DPPH}$ and $\mathrm{H}_{2} \mathrm{O}_{2}$ free radicals in vivo by title compounds $\mathbf{5 a}-\mathbf{j}$ has been determined by studying the molecular docking interactions. As such, the threedimensional crystalline structural information of identified proteins of the study were attained from protein data bank (as $\mathrm{pdb}$ files) and reinvigorated them by removing bound water, ligands, and other cofactors present in their vicinity. The .mol2 and.$p d b$ database files of $\mathbf{5} \mathbf{a}-\mathbf{j}$ ligands were produced from ChemBioOffice software (ChemBio3D ultra 14.0 suite) and docked them for the selected proteins on Swiss Dock software. ${ }^{77}$ The interactive docking poses were considered and captured at energy-minimized optimization conditions with 0.100 of minimum root-mean standard deviation (RMSD) gradient and the interacting binding postures are imagined through UCSF Chimera. ${ }^{78}$ The potential and highest binding energies originated with proper ligand-protein interactions of $\mathbf{5 a}-\mathbf{j}$ with target protein receptors in chain $\mathrm{C}$ of $1 \mathrm{DNU}$ protein and chain A of 4M7E protein, respectively, for the antioxidant and plant growth regulatory activities and were accounted in macromolecular structural atmosphere and acknowledged that compounds $\mathbf{5 a}-\mathbf{j}$ as efficiently bound with the proteins considered for the study and presented in Tables $3-6$.

4.6. ADMET Properties. The ADMET properties of synthesized compounds $\mathbf{5 a - j}$ have been calculated on preADMET online server ${ }^{79,80}$ and which assisted us to understand their potentialities like in vivo BBB penetration, $\%$ HIA, in vitro Caco-2 cell permeability, in vitro Maden Darby Canine kidney (MDCK) cell permeability, and in vitro PPB properties. In continuance, the prediction of tumorigenic, mutagenic, reproductive, and irritant effects has assisted in ascertaining the toxicity properties. The BBB is confined with profoundly bound endothelial cells that constrain a compound's ability to be conceded into the blood stream via the directed route. The analysis of $\mathrm{BBB}$ penetration rate (in terms of concentration ration, i.e., [brain]/[blood]) supported us to inspect the ability of an entity to penetrate over BBB, which is dynamic in assigning CNS activity to the libraries of pharmacophoric assets of a compound. The compounds proficient to pass via $\mathrm{BBB}$ are denoted as CNS active (where, $\mathrm{BBB}$ penetration rate $>0.40$ ) and unable to pass are denoted as CNS inactive (where, BBB penetration rate < 0.40). Similarly, Caco-2 (human colon adenocarcinoma based cells) cells associates by an intestinal epithelium system in multiple drug transport avenues such as transcellular, paracellular, and active efflux transports. The compounds with in vitro Caco- 2 cell permeability value $<4$ are assigned as poor, the permeability in the range of $4-70$ is assigned as moderate, and permeability value $>70$ is assigned as extremely permeable and are efficiently transported to biochemical and cellular processes. Moreover, the extent of PPB influences distribution level of unbound quantity of compound in body tissues and distributed over cellular sites of action and hence stimulates to metabolize and excrete from systems. The \% PPB in vitro classifies the compounds as strong if $\%$ PPB $>90 \%$ and as weak if $\% \mathrm{PPB}<90 \%$, which eventually reflects its potentiality. Moreover, the MDCK cell system is recognized as a sensible system to filter out the prompt permeability of a compound and to decide its potentiality as cellular life span is lower than the life span of Caco- 2 cells and therefore the correspondence stands high. Mostly, in vitro MDCK permeability <25 describes compound as poorly permeable, permeability in the range of 25-500 designated as sensibly permeable, and permeability $>500$ designated as greatly permeable. Likewise, the \% HIA is deliberated as the percentage of an orally administered drug compound into the hepatic portal vein. Generally, it is accounted for ample bioavailability and absorption measured based on the ratio of cumulative excretion in bile, urine, and feces. The \% HIA ranging from 0 to 20 entitles poor, 20-70 
entitles moderate, and 70-100 entitles good absorbance of a compound under study. Coming to the toxicology perspectives, it is important to consider the toxicology properties of an entity under study so as to ignore the toxicity risks during the design itself. The negative magnitude of toxicology for a compound is the outcome of its safer drug property as they are reclining to carcinogenicity, mutagenicity, and HERG (human ether-a-go-go related gene) channel inhibition and its administration in vivo as presented in Table 7. This type of complementary study ascertains a chemical entity as safer drugs.

4.7. QSAR Studies. Many proposed drugs do not come to the clinical stage because of their poor ADMET liabilities, but the worthy oral bioavailability can be realized them by right poise amidst its partition and solubility. ${ }^{81}$ Computationally, Lipinski's rule of five ${ }^{82}$ is considered for screening newer molecules to testify their potentiality as it states that (i) molecular weight $\leq 500 \mathrm{Da}$; (ii) octanol/water partition coefficient $(\log P) \leq 5$; (iv) number of hydrogen bond donors $\leq 5$; and (iii) number of hydrogen bond acceptors $\leq 10$ and summarizes the Lipinski parameters (molecular weight, hydrogen bond acceptors, hydrogen bond donors, molecular refractivity, and octanol to water partition coefficient). The drug-like properties predicted by Molinspiration ${ }^{83}$ are very sturdy and work on the summation of fragment contributions and handling most of the organic compounds to compute and to know the structural sensitivity in visualizing the significant molecular properties like Veber parameters (number of rotatable bonds and total polar surface area in addition to Lipinski parameters) and other parameters like number of hydrophobic atoms; van der Waals volume, density, solubility, calculated octanol to water partition coefficient and percentage of absorption) has been considered and all the quantitative structure-activity relationship descriptors were obtained and presented in Table 8 .

In this QSAR analysis study, molecular descriptors and fingerprints both play an important role as they are mathematical representations of chemical entities and serves as the data analysis methodological input sources in building QSAR models. ${ }^{84-86}$ In detail, molecular descriptors are the experimental results of a molecule according to their theoretically derived properties, which helps in understanding the molecular structure and biological activity of the compounds under study from different facets. ${ }^{87-89}$ In complementary molecular descriptors and fingerprint properties, both portray a vital role in QSAR analysis and in turn in the drug discovery process. ${ }^{90-93}$ The fingerprint properties of $\mathbf{5 a}-\mathbf{j}$ have been predicted from the ChemDes server, ${ }^{94,95}$ an integrated aid for the computing the results. Here, the QSAR results were predicted in MOPAC Cartesian format, a semiempirical molecular orbital package to scrutinize molecular structures and is widely accepted for the prediction of QSAR and other drug discovery studies. These computational chemical studies were performed by modified neglect of diatomic overlap, a semiempirical approach for calculating molecular electronic structural quantum, which is designed on neglect of diatomic differential overlap integral approximation process and the results are presented in Table 9.

4.8. Bioactivity and Toxicity Risk Studies. The drug-like property profiles of compounds $\mathbf{5 a}-\mathbf{j}$ have been assessed on Molinspiration cheminformatics software tool, ${ }^{66}$ viz., v2018.10 Molinspiration engine for property exploration and v2018.03 Molinspiration engine for bioactivity score evaluations. This evaluation revealed the bioactivity and nontoxic properties such as KI (kinase inhibitor), GPCR (G protein-coupled receptor) ligand property, ICM (ion channel modulator), and NRL (nuclear receptor ligand) interactions, and EI (enzyme inhibitor) and PI (protease inhibitor) properties, drug-likeness, and drug scores and mutagenic, tumorigenic, irritant, and reproductive effect of the synthesized compounds have been evaluated and proved as safer drugs. On the other hand, drug properties mounted with the multifarious offset of a set of structural features and molecular properties, and its evaluation helps to evaluate the close approximation of a molecule under investigation with the notorious drugs. Hence, these toxicity risk profiles and drug property parameters have predicted by the Osiris online property explorer toolkit ${ }^{69}$ and consolidated the properties under the head of bioactivity and toxicity risk studies and are presented in Table 10. This study helped in considering the physicochemical interactions of the synthesized compounds against the targeted domains and eventually facilitated for determining corresponding drug properties by comparing with the bioactivity properties and toxicity risk profile studies.

\section{ASSOCIATED CONTENT}

\section{SI Supporting Information}

The Supporting Information is available free of charge at https://pubs.acs.org/doi/10.1021/acsomega.0c05302.

Spectra of compounds $\mathbf{5 a - j}(\mathrm{PDF})$

\section{AUTHOR INFORMATION}

\section{Corresponding Authors}

Suresh Reddy Cirandur - Department of Chemistry, Sri Venkateswara University, Tirupati 517502, Andhra Pradesh, India; 이이.org/0000-0002-9804-9683; Email: csrsvu@ gmail.com

Visweswara Rao Pasupuleti - Department of Biomedical Sciences and Therapeutics, Faculty of Medicine and Health Sciences, Universiti Malaysia Sabah, Kota Kinabalu 88400, Sabah, Malaysia; Email: pvrao@ums.edu.my

\section{Authors}

Maheshwara Reddy Nadiveedhi - Department of Chemistry, Sri Venkateswara University, Tirupati 517502, Andhra Pradesh, India

Poojith Nuthalapati - Sri Ramachandra Institute of Higher Education and Research, Chennai 600116, Tamil Nadu, India

Mohan Gundluru - Department of Chemistry and DSTPURSE Centre, Sri Venkateswara University, Tirupati 517502, Andhra Pradesh, India

Mohan Reddy Yanamula - Department of Biotechnology, Sri Venkateswara University, Tirupati 517502, Andhra Pradesh, India

Saritha Venkatareddy Kallimakula - Department of Biotechnology, Sri Venkateswara University, Tirupati 517502, Andhra Pradesh, India

Vijaya Kumar Reddy Avula - Chemical Engineering Institute, Ural Federal University, Yekaterinburg 620002, Russian Federation

Swetha Vallela - Chemical Engineering Institute, Ural Federal University, Yekaterinburg 620002, Russian Federation

Grigory Vasilievich Zyryanov - Chemical Engineering Institute, Ural Federal University, Yekaterinburg 620002, 
Russian Federation; Ural Division of the Russian Academy of Sciences, I. Ya. Postovskiy Institute of Organic Synthesis, Yekaterinburg 620219, Russian Federation

Satheesh Krishna Balam - Department of Chemistry, Sri Venkateswara University, Tirupati 517502, Andhra Pradesh, India

Complete contact information is available at: https://pubs.acs.org/10.1021/acsomega.0c05302

\section{Notes}

The authors declare no competing financial interest.

\section{ACKNOWLEDGMENTS}

The author M.R.N. expresses thanks to the Department of Science and Technology, New Delhi, India, for the financial support under DST-INSPIRE Fellowship program no. DST/ INSPIRE Fellowship/IF150757, dated: 14/01/16. The author M.G. expresses thanks to DST-PURSE $2^{\text {nd }}$ Phase Programme facilitated at Sri Venkateswara University, Tirupati, India, by Department of Science and Technology, New Delhi, India [17118-UGC-III(3)/DST-PURSE 2nd Phase/2017, Dt: 2308-2018], for funding. The authors V.K.R.A. and G.V.Z. are thankful to Ural Federal University for support and acknowledge the financial support of the Russian Science Foundation, Moscow, Russian Federation (RSF grant no.: 18-13-00365). The authors also acknowledge C. Devendranath Reddy (Retd.), Sri Venkateswara University, Tirupati, India, for the guidance.

\section{REFERENCES}

(1) Naidu, K. R. M.; Rao, P. V.; Raju, C. N.; Srinivasulu, K. Synthesis and Antioxidant Activity of Substituted-1,3,2-Diazaphosphole 1-Oxides. Arch. Pharm. Chem. Life Sci. 2011, 344, 765-770.

(2) Rao, A. J.; Rao, P. V.; Rao, V. ..; Mohan, C.; Raju, C. N.; Reddy, C. S. Microwave Assisted One-pot Synthesis of Novel $\alpha$-Aminophosphonates and heir Biological Activity. Bull. Korean Chem. Soc. 2010, 31, 1863-1868.

(3) Reddy, S. S.; Rao, V. K.; Krishna, B. S.; Reddy, C. S.; Rao, P. V.; Raju, C. N. Synthesis, Antimicrobial, and Antioxidant Activity of New $\alpha$-Aminophosphonates. Phosphorus, Sulfur Silicon Relat. Elem. 2011, 186, 1411-1421.

(4) Balam, S. K.; Krishnammagari, S. K.; Soora Harinath, J.; Sthanikam, S. P.; Chereddy, S. S.; Pasupuleti, V. R.; Yellapu, N. K.; Peddiahgari, V. G. R.; Cirandur, S. R. Synthesis of N-(3-picolyl)-based 1,3,2 $\lambda 5$-benzoxazaphosphinamides as potential $11 \beta$-HSD1 enzyme inhibitors. Med. Chem. Res. 2015, 24, 1119-1135.

(5) Prasad, S. S.; Kumar, K. S.; Jayaprakash, S. H.; Krishna, B. S.; Sundar, C. S.; Rao, P. V.; Babu, T. M.; Rajendra, W.; Reddy, C. S. Design, Synthesis, Antioxidant, and Anti-Breast Cancer Activities of Novel Diethyl(alkyl/aryl/heteroarylamino)(4-(pyridin-2-yl)phenyl)methylphosphonates. Arch. Pharm. Chem. Life Sci. 2013, 346, 380391.

(6) Xu, Y.; Yan, K.; Song, B.; Xu, G.; Yang, S.; Xue, W.; Hu, D.; Lu, P.; Ouyang, G.; Jin, L.; Chen, Z. Synthesis and Antiviral Bioactivities of $\alpha$-Aminophosphonates Containing Alkoxyethyl Moieties. Molecules 2006, 11, 666-676.

(7) Rezaei, Z.; Firouzabadi, H.; Iranpoor, N.; Ghaderi, A.; Jafari, M. R.; Jafari, A. A.; Zare, H. R. Design and one-pot synthesis of $\alpha$ aminophosphonates and bis( $\alpha$-aminophosphonates) by iron(III) chloride and cytotoxic activity. Eur. J. Med. Chem. 2009, 44, 42664275.

(8) Vahdat, S. M.; Baharfar, R.; Tajbakhsh, M.; Heydari, A.; Baghbanian, S. M.; Khaksar, S. Organocatalytic synthesis of $\alpha$-hydroxy and $\alpha$-aminophosphonates. Tetrahedron Lett. 2008, 49, 6501-6504.
(9) Akbari, J.; Heydari, A. A sulfonic acid functionalized ionic liquid as a homogeneous and recyclable catalyst for the one-pot synthesis of $\alpha$-aminophosphonates. Tetrahedron Lett. 2009, 50, 4236-4238.

(10) Karimi-Jaberi, Z.; Amiri, M. One-pot synthesis of $\alpha$-aminophosphonates catalyzed by boric acid at room temperature. Heteroat. Chem. 2010, 21, 96-98.

(11) Ambica, S.; Kumar, K. K.; Taneja, S. C.; Hundal, M. S.; Kapoor, K. K. One-pot synthesis of $\alpha$-aminophosphonates catalyzed by antimony trichloride adsorbed on alumina. Tetrahedron Lett. 2008, 49, 2208-2212.

(12) Kafarski, P.; Lejczak, B. Biological activity of aminophosphonic acids. Phosphorus, Sulfur Silicon Relat. Elem. 1991, 63, 193-215.

(13) Smith, A. B., III; Taylor, C. M.; Benkovic, S. J.; Hirschmann, R. Peptide bond formation via catalytic antibodies: Synthesis of a novel phosphonate diester hapten. Tetrahedron Lett. 1994, 35, 6853-6856.

(14) Galezowska, J.; Gumienna-Kontecka, E. Phosphonates, their complexes and bio-applications: A spectrum of surprising diversity. Coord. Chem. Rev. 2012, 256, 105-124.

(15) Hosseini-Sarvari, M. TiO2 as a new and reusable catalyst for one-pot three-component syntheses of $\alpha$-aminophosphonates in solvent-free conditions. Tetrahedron 2008, 64, 5459-5466.

(16) Bhagat, S.; Chakraborti, A. K. An Extremely Efficient ThreeComponent Reaction of Aldehydes/Ketones, Amines, and Phosphites (Kabachnik-Fields Reaction) for the Synthesis of $\alpha$-Aminophosphonates Catalyzed by Magnesium Perchlorate. J. Org. Chem. 2007, 72, $1263-1270$

(17) Makhaeva, G. F.; Malygin, V. V.; Aksinenko, A. Y.; Sokolov, V. B.; Strakhova, N. N.; Rasdolsky, A. N.; Richardson, R. J.; Martynov, I. V. Fluorinated $\alpha$-aminophosphonates-a new type of irreversible inhibitors of serine hydrolases. Dokl. Biochem. Biophys. 2005, 400, 92-95.

(18) Pan, W.; Ansiaux, C.; Vincent, S. P. Synthesis of acyclic galactitol- and lyxitol-aminophosphonates as inhibitors of UDPgalactopyranose mutase. Tetrahedron Lett. 2007, 48, 4353-4356.

(19) Huang, j.; Chen, R. An overview of recent advances on the synthesis and biological activity of ?-aminophosphonic acid derivatives. Heteroat. Chem. 2000, 11, 480-492.

(20) Kiran, Y. B.; Vasu Govardhana Reddy, P.; Devendranath Reddy, C.; Gunasekar, D.; Eswara Reddy, N. P. Synthesis of [3-(3Chloro-4-fluorophenyl)-2-oxo-3,4-dihydro-2H-2 $\lambda$ - benzo[e][1,3,2]oxazaphosphinin-2-yl]-(aryl/alkyl) Methanols and Their Bioactivity on Sugarcane Smut. J. Agric. Food Chem. 2007, 55, 6933-6939.

(21) Bhagat, S.; Chakraborti, A. K. Zirconium(IV) Compounds As Efficient Catalysts for Synthesis of $\alpha$-Aminophosphonates. J. Org. Chem. 2008, 73, 6029-6032.

(22) Heydari, A.; Khaksar, S.; Tajbakhsh, M. Trifluoroethanol as a metal-free, homogeneous and recyclable medium for the efficient onepot synthesis of $\alpha$-amino nitriles and $\alpha$-amino phosphonates. Tetrahedron Lett. 2009, 50, 77-80.

(23) Kafarski, P.; Lejczak, B.; Slesak, E.; Przetocki, J. Plant growth regulating activity of aromatic aminophosphonates and their short peptides. Pestic. Sci. 1989, 25, 137-143.

(24) Wieczorek, P.; Miliszkiewicz, D.; Lejczak, B.; Soroka, M.; Kafarski, P. Plant-growth-regulating N-(phosphonoacetyl)amines. Pestic. Sci. 1994, 40, 57-62.

(25) Hassall, C. H. Alafosfalin (Ro 03-7008, Alaphosphin). In Modes and mechanisms of microbial growth inhibitors. Antibiotics; Hahn, F. E., Ed.; Springer: Berlin, Heidelberg, 1983; Vol. 6; pp 1-11.

(26) Matveeva, E. D.; Podrugina, T. A.; Prisyazhnoi, M. V.; Rusetskaya, I. N.; Zefirov, N. S. Three-component catalytic method for synthesis of $\alpha$-amino phosphonates with the use of $\alpha$-amino acids as amine component. Russ. Chem. Bull. 2007, 56, 798-805.

(27) Matveeva, E. D.; Podrugina, T. A.; Prisyajnoy, M. V.; Zefirov, N. S. Ketones in the catalytic three-component "one-pot" KabachnikFields synthesis of $\alpha$-amino phosphonates. Russ. Chem. Bull. 2006, 55, 1209-1214.

(28) Salmeia, K. A.; Gaan, S. An overview of some recent advances in DOPO-derivatives: Chemistry and flame retardant applications. Polym. Degrad. Stab. 2015, 113, 119-134. 
(29) Sobkowski, M.; Kraszewski, A.; Stawinski, J. Recent advances in H-phosphonate chemistry. Part 2. Synthesis of C-phosphonate derivatives. In Phosphorus chemistry II. Topics in current chemistry; Montchamp, J. L., Ed.; Springer: Cham, 2014; Vol. 361; pp 179-216.

(30) Zhao, R.; Rupper, P.; Gaan, S. Recent development in phosphonic acid-based organic coatings on Aluminum. Coatings 2017, 7, 133.

(31) Qiu, J.-J.; Xue, Q.; Liu, Y.-Y.; Pan, M.; Liu, C.-M. A New Polymer Containing $\alpha$-Aminophosphonate Unit Used as Reactive, Halogen-Free Flame Retardant for Epoxy Resins. Elem 2014, 189, 361-373.

(32) Crépy, K. V. L.; Imamoto, T. New P-chirogenic phosphine ligands and their use in catalytic asymmetric reactions. In New aspects in phosphorus chemistry III. Topics in current chemistry; Majoral, J.-P., Ed.; Springer: Berlin, Heidelberg, 2003; Vol 229; pp 27-37.

(33) Demchuk, O. M.; Jasiński, R. Organophosphorus ligands: Recent developments in design, synthesis, and application in environmentally benign catalysis. Phosphorus, Sulfur Silicon Relat. Elem. 2016, 191, 245-253.

(34) Anusha, G.; Reddy, M. V. K.; Govardhana Reddy, P. V. SingaCycleTM-A1-catalyzed successive Suzuki-Miyaura and Buchwald couplings for the synthesis of various new pyridine analogues. ChemistrySelect 2018, 3, 13182-13190.

(35) Reddy, S. M.; Reddy, B. N.; Motakatla, V. K. R.; Gokanapalli, A.; Madhvesh, P.; Reddy, P. V. G. Pd-NHC catalyzed Suzuki-Miyaura couplings on 3-bromo-9H-pyrido[2,3-b]indole-6-sulfonamide. Synth. Commun. 2019, 49, 1987-1996.

(36) Gokanapalli, A.; Motakatla, V. K. R.; Peddiahgari, V. G. R. Benzimidazole bearing Pd-PEPPSI complexes catalyzed direct $\mathrm{C} 2$ arylation/heteroarylation of $\mathrm{N}$-substituted benzimidazoles. Appl. Organomet. Chem. 2020, 34, No. e5869.

(37) Hiratake, J.; Oda, J. i. Aminophosphonic and aminoboronic acids as key elements of a transition state analogue inhibitor of enzymes. Biosci., Biotechnol., Biochem. 1997, 61, 211-218.

(38) Jane, D. E. Neuroactive aminophosphonic and aminophosphinic acid derivatives. In Aminophosphonic and aminophosphinic acids, Chemistry and Biological activity; Kukhar, V. P., Hudson, H. R., Eds.; Wiley: Chichester, New York, U.K., 2000; pp 483-536.

(39) Engel, R.; Cohen, J. I. Synthesis of organophosphorus compounds from elemental phosphorus. Synthesis of carbonphosphorus bonds, 2nd ed.; CRC Press: Boca Raton, FL, USA, 2003; pp 9-26.

(40) Lin, B.; Shi, S.; Lin, R.; Cui, Y.; Fang, M.; Tang, G.; Zhao, Y. Cobalt-Catalyzed Oxidative $\mathrm{C}(\mathrm{sp} 3)-\mathrm{H}$ Phosphonylation for $\alpha$-Aminophosphonates via $\mathrm{C}(\mathrm{sp} 3)-\mathrm{H} / \mathrm{P}(\mathrm{O})-\mathrm{H}$ Coupling. J. Org. Chem. 2018, 83, 6754-6761.

(41) Zhu, Z.-Q.; Xiao, L.-J.; Guo, D.; Chen, X.; Ji, J.-J.; Zhu, X.; Xie, Z.-B.; Le, Z.-G. Cobalt-Catalyzed Oxidative Phosphonylation of $\alpha$ Amino Acid Derivatives and $\alpha$-Amino Ketones for $\alpha$-Aminophosphonates. J. Org. Chem. 2019, 84, 435-442.

(42) Peng, Y.; Fan, Y.-H.; Li, S.-Y.; Li, B.; Xue, J.; Deng, Q.-H. IronCatalyzed Nitrene Transfer Reaction of 4-Hydroxystilbenes with Aryl Azides: Synthesis of Imines via $\mathrm{C}=\mathrm{C}$ Bond Cleavage. Org. Lett. 2019, 21, 8389-8394.

(43) Kolli, M. K.; Palani, E.; Govindasamy, C.; Katta, V. R. Highly efficient one-pot synthesis of $\alpha$-aminophosphonates using nanoporous AlSBA-15 catalyst in a three-component system. Res. Chem. Intermed. 2020, 46, 1047-1064.

(44) Piri, T.; Peymanfar, R.; Javanshir, S.; Amirnejat, S. Magnetic BaFe12O19/Al2O3: An Efficient Heterogeneous Lewis Acid Catalyst for the Synthesis of $\alpha$-Aminophosphonates (Kabachnik-Fields Reaction). Catal. Lett. 2019, 149, 3384-3394.

(45) Maghsoodlou, M. T.; Khorassani, S. M. H.; Hazeri, N.; Rostamizadeh, M.; Sajadikhah, S. S.; Shahkarami, Z.; Maleki, N. An efficient synthesis of $\alpha$-Amino phosphonates using silica sulfuric acid as a heterogeneous catalyst. Heteroat. Chem. 2009, 20, 316-318.

(46) Matveeva, E. D.; Podrugina, T. A.; Kolesnikova, I. N.; Zefirov, N. S. Benzoylhydrazones in catalytic hydrophosphorylation. Russ. Chem. Bull. 2010, 59, 411-417.
(47) Liu, Y.; Zhou, K.; Shu, H.; Liu, H.; Lou, J.; Guo, D.; Wei, Z.; Li, $\mathrm{W}$. Switchable synthesis of furfurylamine and tetrahydrofurfurylamine from furfuryl alcohol over RANEY® Nickel. Catal. Sci. Technol. 2017, 7, 4129-4135.

(48) Nishimura, S.; Mizuhori, K.; Ebitani, K. Reductive amination of furfural toward furfurylamine with aqueous ammonia under hydrogen over Ru-supported catalyst. Res. Chem. Intermed. 2016, 42, 19-30.

(49) Chatterjee, M.; Ishizaka, T.; Kawanami, H. Reductive amination of furfural to furfurylamine using aqueous ammonia solution and molecular hydrogen: An environmentally friendly approach. Green Chem. 2016, 18, 487-496.

(50) Dunbabin, A.; Subrizi, F.; Ward, J. M.; Sheppard, T. D.; Hailes, H. C. Furfurylamines from biomass: Transaminase catalysed upgrading of furfurals. Green Chem. 2017, 19, 397-404.

(51) Nikolov, P. Y.; Yaylayan, V. A. Role of the ribose-specific marker furfuryl-amine in the formation of aroma active 1-(furan-2ylmethyl)-1h-pyrrole (or furfuryl-pyrrole) derivatives. J. Agric. Food Chem. 2012, 60, 10155-10161.

(52) Subba Rao, D.; Rasheed, S.; Thaslim Basha, S. K.; Naga Raju, C.; Naresh, K. SiO2/ZnCl2 catalyzed $\alpha$-aminophosphonates and phosphonated $\mathrm{N}$-(substituted phenyl) sulfonamides of 2-aminothiophene: Synthesis and biological evaluation. Der Pharma Chem. 2013, 5, 61-74.

(53) Keivanloo, A.; Bakherad, M.; Bahramian, B.; Baratnia, S. Silicasupported zinc bromide $(\mathrm{ZnBr} 2 / \mathrm{SiO} 2)$ : a highly efficient heterogeneous catalyst for coupling acid chlorides with terminal alkynes. Tetrahedron Lett. 2011, 52, 1498-1502.

(54) Fan, G.; Luo, S.; Wu, Q.; Fang, T.; Li, J.; Song, G. ZnBr2 supported on silica-coated magnetic nanoparticles of $\mathrm{Fe} 3 \mathrm{O} 4$ for conversion of CO2 to diphenyl carbonate. RSC Adv. 2015, 5, 5647856485 .

(55) Ak, T.; Gülçin, İ. Antioxidant and radical scavenging properties of curcumin. Chem.-Biol. Interact. 2008, 174, 27-37.

(56) Gülçin, İ. Antioxidant activity of food constituents: An overview. Arch. Toxicol. 2012, 86, 345-391.

(57) Taslimi, P.; Gulçin, İ. Antioxidant and anticholinergic properties of olivetol. J. Food Biochem. 2018, 42, No. e12516.

(58) Gulcin, İ. Antioxidants and antioxidant methods: An updated overview. Arch. Toxicol. 2020, 94, 651-715.

(59) Duan, X.; Wu, G.; Jiang, Y. Evaluation of the Antioxidant Properties of Litchi Fruit Phenolics in Relation to Pericarp Browning Prevention. Molecules 2007, 12, 759-771.

(60) Halliwell, B. Free radicals, antioxidants, and human disease: curiosity, cause, or consequence? Lancet 1994, 344, 721-724.

(61) Hanson, J. E.; Kaplan, A. P.; Bartlett, P. A. Phosphonate analogs of carboxypeptidase A substrates are potent transition-state analog inhibitors. Biochemistry 1989, 28, 6294-6305.

(62) Smith, I. K.; Fowden, L. A Study of Mimosine Toxicity in Plants. J. Exp. Bot. 1966, 17, 750-761.

(63) Opera, T. I.; Matter, H. Integrating virtual screening in lead discovery. Curr. Opin. Chem. Biol. 2004, 8, 349-358.

(64) Ertl, P.; Rohde, B.; Selzer, P. Fast calculation of molecular polar surface area as a sum of fragment-based contributions and its application to the prediction of drug transport properties. J. Med. Chem. 2000, 43, 3714-3717.

(65) da Silva, M. M.; Comin, M.; Duarte, T. S.; Foglio, M. A.; de Carvalho, J. E.; do Vieira, M. C.; Formagio, A. S. N. Synthesis, antiproliferative activity and molecular properties predictions of galloyl derivatives. Molecules 2015, 20, 5360-5373.

(66) https://www.organic-chemistry.org/prog/peo/druglikeness. html (accessed on October 17, 2020).

(67) Alafeefy, A. M.; Alqasoumi, S. I.; Ashour, A. E.; Masand, V.; AlJaber, N. A.; Hadda, T. B.; Mohamed, M. A. Quinazoline-tyrphostin as a new class of antitumor agents, molecular properties prediction, synthesis and biological testing. Eur. J. Med. Chem. 2012, 53, 133140.

(68) Köse, L. P.; Gülçin, İ.; Gören, A. C.; Namiesnik, J.; MartinezAyala, A. L.; Gorinstein, S. LC-MS/MS analysis, antioxidant and 
anticholinergic properties of galanga (Alpinia officinarum Hance) rhizomes. Ind. Crops Prod. 2015, 74, 712-721.

(69) Bursal, E.; Gülçin, İ. Polyphenol contents and in vitro antioxidant activities of lyophilised aqueous extract of kiwifruit (Actinidia deliciosa). Food Res. Int. 2011, 44, 1482-1489.

(70) Gülçin, İ.; Bursal, E.; Şehitoğlu, M. H.; Bilsel, M.; Gören, A. C. Polyphenol contents and antioxidant activity of lyophilized aqueous extract of propolis from Erzurum, Turkey. Food Chem. Toxicol. 2010, 48, 2227-2238

(71) Öztaşkın, N.; Çetinkaya, Y.; Taslimi, P.; Göksu, S.; Gülçin, İ. Antioxidant and acetylcholinesterase inhibition properties of novel bromophenol derivatives. Bioorg. Chem. 2015, 60, 49-57.

(72) Gülçin, İ. Antioxidant activity of l-adrenaline: A structureactivity insight. Chem.-Biol. Interact. 2009, 179, 71-80.

(73) Gülçin, İ. Antioxidant properties of resveratrol: A structureactivity insight. Innovative Food Sci. Emerging Technol. 2010, 11, 210218.

(74) Gülçin, İ. Antioxidant activity of Eugenol: A structure-activity relationship study. J. Med. Food 2011, 14, 975-985.

(75) Bursal, E.; Gülçin, I. Polyphenol contents and in vitro antioxidant activities of lyophilised aqueous extract of kiwifruit (Actinidia deliciosa). Food Res. Int. 2011, 44, 1482-1489.

(76) Köse, L. P.; Gülçina, I.; Gören, A. C.; Namiesnik, J.; MartinezAyala, A. L.; Gorinstein, S. LC-MS/MS analysis, antioxidant and anticholinergic properties of galanga (Alpinia officinarum Hance) rhizomes. Ind. Crops Prod. 2015, 74, 712-721.

(77) http://www.swissdock.ch/docking (accessed on September 23, 2020).

(78) Pettersen, E. F.; Thomas, D. G.; Conrad, C. H.; Gregory, S. C.; Daniel, M. G.; Elaine, C. M.; Thomas, E. F. UCSF Chimeraea visualization system for exploratory research and analysis. J. Comput. Chem. 2004, 25, 1605-1612.

(79) Bakht, M. A.; Shahar, M. Y.; Sami, G. A. H.; Saleh, I. A. Q.; Abdul, S. Molecular properties prediction, synthesis and antimicrobial activity of some newer oxadiazole derivatives. Eur. J. Med. Chem. 2010, 45, 5862-5869.

(80) http://preadmet.bmdrc.org/ (accessed on October 11, 2020).

(81) Muratov, E. N.; Jürgen, B.; Robert, P. S.; Igor, V. T.; Dmitry, F.; Vladimir, P.; Tudor, I. O.; Igor, I. B.; Alexandre, V.; Adrian, R.; Olexandr, I.; Stefano, C.; Denis, F.; Yoram, C.; Alan, A. G.; David, A. W.; Dimitris, A.; Artem, C.; Alexander, T. QSAR without borders. Chem. Soc. Rev. 2020, 49, 3525-3564.

(82) Lipinski, C. A.; Franco, L.; Beryl, W. D.; Paul, J. F. Experimental and computational approaches to estimate solubility and permeability in drug discovery and development settings. Adv. Drug Delivery Rev. 2001, 46, 3-26.

(83) http://www.molinspiration.com/cgi-bin/properties (accessed on October 16, 2020).

(84) Stumpfe, D.; Dimova, D.; Bajorath, J. Computational method for the systematic identification of analog series and key compounds representing series and their biological activity profiles. J. Med. Chem. 2016, 59, 7667-7676.

(85) Hu, Y.; Stumpfe, D.; Bajorath, J. Lessons learned from molecular scaffold analysis. J. Chem. Inf. Model. 2011, 51, 1742-1753.

(86) Gupta-Ostermann, D.; Bajorath, J. The 'SAR Matrix' method and its extensions for applications in medicinal chemistry and chemogenomics. F1000Research 2014, 3, 113.

(87) Maggiora, G.; Vogt, M.; Stumpfe, D.; Bajorath, J. Molecular similarity in medicinal chemistry. J. Med. Chem. 2014, 57, 3186-3204.

(88) Hu, X.; Hu, Y.; Vogt, M.; Stumpfe, D.; Bajorath, J. MMP-cliffs: systematic identification of activity cliffs on the basis of matched molecular pairs. J. Chem. Inf. Model. 2012, 52, 1138-1145.

(89) Stumpfe, D.; Bajorath, J. Similarity searching. Wiley Interdiscip. Rev.: Comput. Mol. Sci. 2011, 1, 260-282.

(90) Peltason, L.; Iyer, P.; Bajorath, J. Rationalizing threedimensional activity landscapes and the influence of molecular representations on landscape topology and the formation of activity cliffs. J. Chem. Inf. Model. 2010, 50, 1021-1033.
(91) Geppert, H.; Horváth, T.; Gärtner, T.; Wrobel, S.; Bajorath, J. Support-vector-machine-based ranking significantly improves the effectiveness of similarity searching using $2 \mathrm{D}$ fingerprints and multiple reference compounds. J. Chem. Inf. Model. 2008, 48, 742-746.

(92) Bajorath, J.; Peltason, L.; Wawer, M.; Guha, R.; Lajiness, M. S.; Van Drie, J. H. Navigating structure-activity landscapes. Drug Discovery Today 2009, 14, 698-705.

(93) Peltason, L.; Bajorath, J. SAR Index: Quantifying the Nature of Structure-Activity Relationships. J. Med. Chem. 2007, 50, 55715578.

(94) http://www.scbdd.com/mopac-optimization/optimize/ (accessed on November 18, 2020).

(95) Dong, J.; Cao, D.-SC.; Hong, Y. M.; Shao, L.; Bai, C. D.; Yong, H. Y.; Ning, N. W.; Ai, P. L.; Wen, B. Z.; Alex, C. ChemDes: an integrated web-based platform for molecular descriptor and fingerprint computation. J. Cheminf. 2015, 7, 60. 